\title{
THE
}

\section{Chemical characteristics of continental outflow from Asia to the troposphere over the western Pacific Ocean during September-October 1991: Results from PEM-West A}

R. W. Talbot

J. E. Dibb

K. I. Klemm

J. D. Bradshaw

S. T. Sandholm

See next page for additional authors

Follow this and additional works at: https://digitalcommons.uri.edu/gsofacpubs

Terms of Use

All rights reserved under copyright.

\section{Citation/Publisher Attribution}

Talbot, R. W., et al. (1996), Chemical characteristics of continental outflow from Asia to the troposphere over the western Pacific Ocean during September-October 1991: Results from PEM-West A, J. Geophys. Res., 101(D1), 1713-1725, doi: 10.1029/95JD01044.

Available at: https://doi.org/10.1029/95JD01044

This Article is brought to you for free and open access by the Graduate School of Oceanography at DigitalCommons@URI. It has been accepted for inclusion in Graduate School of Oceanography Faculty Publications by an authorized administrator of DigitalCommons@URI. For more information, please contact digitalcommons-group@uri.edu. 


\section{Authors}

R. W. Talbot, J. E. Dibb, K. I. Klemm, J. D. Bradshaw, S. T. Sandholm, D. R. Blake, G. W. Sachse, J. Collins, Brian G. Heikes, G. L. Gregory, B. E. Anderson, H. B. Singh, D. C. Thornton, and John Merrill 


\title{
Chemical characteristics of continental outflow from Asia to the troposphere over the western Pacific Ocean during September-October 1991: Results from PEM-West A
}

\author{
R. W. Talbot, ${ }^{1}$ J. E. Dibb, ${ }^{1}$ K. I. Klemm, ${ }^{1,2}$ J. D. Bradshaw, ${ }^{3}$ S. T. Sandholm, ${ }^{3}$ D. R. \\ Blake, ${ }^{4}$ G. W. Sachse, ${ }^{5}$ J. Collins, ${ }^{5}$ B. G. Heikes, ${ }^{6}$ G. L. Gregory, ${ }^{5}$ B. E. Anderson, ${ }^{5}$ \\ H. B. Singh, ${ }^{7}$ D. C. Thornton, ${ }^{8}$ and J. T. Merrill ${ }^{6}$
}

\begin{abstract}
An important objective of the Pacific Exploratory Mission-West A (PEM-West A) was the chemical characterization of the outflow of tropospheric trace gases and aerosol particles from the Asian continent over the western Pacific Ocean. This paper summarizes the chemistry of this outflow during the period September - October 1991. The vertical distributions of $\mathrm{CO}, \mathrm{C}_{2} \mathrm{H}_{6}$, and $\mathrm{NO}_{\mathrm{x}}$ showed regions of outflow at altitudes below $2 \mathrm{~km}$ and from 8 to $12 \mathrm{~km}$. Mixing ratios of $\mathrm{CO}$ were $\approx 130$ parts per billion by volume (ppbv), $\approx 1000$ parts per trillion by volume (pptv) for $\mathrm{C}_{2} \mathrm{H}_{6}$, and $\approx 100 \mathrm{pptv}$ for $\mathrm{NO}_{\mathrm{x}}$ in both of these regions. Direct outflow of Asian industrial materials was clearly evident at altitudes below $2 \mathrm{~km}$, where halocarbon tracer compounds such as $\mathrm{CH}_{3} \mathrm{CCl}_{3}$ and $\mathrm{C}_{2} \mathrm{Cl}_{4}$ were enhanced about threefold compared to aged Pacific air. The source attribution of species outflowing from Asia to the Pacific at $8-12 \mathrm{~km}$ altitude was not straightforward. Above $10 \mathrm{~km}$ altitude there were substantial enhancements of $\mathrm{NO}_{y}, \mathrm{O}_{3}, \mathrm{CO}, \mathrm{CH}_{4} \mathrm{SO}_{2}, \mathrm{C}_{2} \mathrm{H}_{6}, \mathrm{C}_{3} \mathrm{H}_{8}, \mathrm{C}_{2} \mathrm{H}_{2}$, and aerosol ${ }^{210} \mathrm{~Pb}$ but not halocarbon industrial tracers. These air masses were rich in nitrogen relative to sulfur and contained ratios of $\mathrm{C}_{2} \mathrm{H}_{2} / \mathrm{CO}$ and $\mathrm{C}_{3} \mathrm{H}_{8} / \mathrm{C}_{2} \mathrm{H}_{6}(\approx 1.5$ and 0.1 respectively) indicative of severalday-old combustion emissions. It is unclear if these emissions were of Asian origin, or if they were rapidly transported to this region from Europe by the high wind speeds in this tropospheric region $\left(60-70 \mathrm{~m} \mathrm{~s}^{-1}\right)$. The significant cyclonic activity over Asia at this time could have transported to the upper troposphere emissions from biomass burning in Southeast Asia or emissions from the extensive use of various biomass materials for cooking and space heating. Apparently, the emissions in the upper troposphere were brought there by wet convective systems since water-soluble gases and aerosols were depleted in these air masses. Near $9 \mathrm{~km}$ altitude there was a distinct regional outflow that appeared to be heavily influenced by biogenic processes on the Asian continent, especially from the southeastern area. These air masses contained $\mathrm{CH}_{4}$ in excess of $1800 \mathrm{ppbv}$, while $\mathrm{CO}_{2}$ and $\mathrm{OCS}$ were significantly depleted (349 - $352 \mathrm{ppmv}$ and $450-500 \mathrm{pptv}$, respectively). This signature seemingly reflected $\mathrm{CH}_{4}$ emissions from wetlands and rice paddies with coincident biospheric uptake of tropospheric $\mathrm{CO}_{2}$ and OCS.
\end{abstract}

\section{Introduction}

The mineralogy of sediments collected from the North Pacific Ocean between $30^{\circ}$ and $40^{\circ} \mathrm{N}$ latitude is identical to that of aeolian mineral particles originating on the Asian continent [Blank et al., 1985]. The transport and deposition of Asian dust materials can,

\footnotetext{
'Institute for the Study of Earth, Oceans, and Space, University of New Hampshire, Durham.

${ }^{2}$ Now at Fraunhofer Institut für Atmosphärische Umweltforschung Garmisch-Partenkirchen, Germany.

${ }^{3}$ School of Earth and Atmospheric Sciences, Georgia Institute of Technology, Atlanta.

${ }^{4}$ Department of Chemistry, University of California-Irvine, Irvine.

${ }^{5}$ NASA Langley Research Center, Hampton, Virginia.

${ }^{6}$ Center for Atmospheric Chemistry, University of Rhode Island, Narragansett.

${ }^{7}$ NASA Ames Research Center, Moffett Field, California.

${ }^{8}$ Department of Chemistry, Drexel University, Philadelphia, Pennsylvania.

Copyright 1996 by the American Geophysical Union.

Paper number 95JD01044.

0148-0227/96/95JD-01044\$05.00
}

in fact, account for a substantial fraction of the nonbiogenic portion of Pacific sediments in this region. Atmospheric studies in the marine boundary layer at numerous island stations in the Pacific confirm the impact of long-range transport of aeolian materials from the Asian continent, that is particularly strong in the February through May time period [Duce et al., 1980]. This seasonal impact is most evident at higher latitudes, presumably resulting from the westerly wind regime there in the large-scale meteorological features [Merrill et al., 1985].

It is well documented that atmospheric nitrate $\left(\mathrm{HNO}_{3}\right.$ vapor + aerosol $\mathrm{NO}_{3}^{-}$) mixing ratios in the boundary layer are consistently larger and more variable over the North Pacific compared to its equatorial and southern counterparts [Savoie et al., 1989; Prospero and Savoie, 1989]. Furthermore, the significant correlation of ${ }^{210} \mathrm{~Pb}$ and nitrate over the North Pacific suggests a continental source for both species [Balkanski et al., 1993]. Indeed, the transport of ${ }^{210} \mathrm{~Pb}$ over the Pacific Ocean appears to be closely tied to aeolian transport of mineral aerosols derived from the extensive arid regions of Asia [Turekian and Cochran, 1981; Uematsu et al., 1983; Prospero et al., 1985]. These atmospheric components show a pronounced annual seasonal cycle in their abundance in boundary layer air over the North Pacific that 
appears to be linked to dust storm activity on the Asian continent [Uematsu et al., 1983].

In contrast to nitrate, data for aerosol $\mathrm{SO}_{4}{ }^{2-}$ do not necessarily imply a strong continental source [Savoie and Prospero, 1989]. The sulfur regime appears to be driven by a general predominance of natural emissions from the North Pacific, mainly of dimethylsulfide [Savoie and Prospero, 1989; Arimoto et al., this issue]. Episodic impact of continental sources on aerosol $\mathrm{SO}_{4}{ }^{2-}$ is evident at some North Pacific locations, particularly those at more northern latitudes (e.g., Midway and Shemya Islands) [Prospero et al., 1985]. The absence of consistent correlation of atmospheric nitrate and ${ }^{210} \mathrm{~Pb}$ with aerosol $\mathrm{SO}_{4}{ }^{2-}$ suggests that these species have different sources and transport characteristics over the North Pacific [Prospero et al., 1985].

At lower latitudes over the Pacific the influence of Asian continental sources is clearly evident during the January to May time frame. Numerous measurements made during the Sea-Air Exchange (SEAREX) program show this impact, including (1) a suite of natural organic materials, many typical of a vegetation origin [Gagosian et al., 1981, 1982]; (2) high-molecular weight organic compounds of anthropogenic nature [Atlas and Giam, 1981]; and (3) lead with a distinct anthropogenic isotopic signature [Settle and Patterson, 1982]; and a broad spectrum of trace metals from natural and anthropogenic sources [Duce et al., 1983].

At mid-Pacific equatorial locations the weak inputs of continental materials during the summer and fall months appear to be derived from continental areas to the east. The lead isotopic signature during these warmer months matches that of a western North American source region [Settle and Patterson, 1982]. The mineralogy of aeolian dust during this period is also distinctly different from that during springtime and indicative of North/South American-derived materials [Buat-Menard et al., 1983].

The ground-based measurements summarized above have provided key information for establishing the basic regime for material transport over the western Pacific Ocean. The NASA Pacific Exploratory Mission over the western (PEM-West A) Pacific in fall 1991 expanded upon ground-based observations by providing information up to an altitude of about $12 \mathrm{~km}$ for a grid $0^{\circ}-40^{\circ} \mathrm{N}$ latitude and $110^{\circ}-180^{\circ} \mathrm{E}$ longitude. The airborne measurements during PEM-West A were conducted in SeptemberOctober 1991 to study budgets of $\mathrm{O}_{3}$ and its precursors, and sulfur, in the troposphere over the western Pacific during the summer/fall period of low aeolian dust outflow from the Asian continent. The objective of this paper is to provide a summary of the general chemical characteristics of continental outflow during PEM-West A. We compared fresh ( $<2$ days from western Pacific rim landmasses) with more aged (2-5 days) continental outflow air masses to examine short-term aging effects on the chemical signatures. Companion papers discuss the details of the chemical gradients [Smyth et al., this issue] in continental outflow relative to aged marine [Gregory et al., this issue] air masses during PEM-West A.

\section{Experiment}

The airborne component of PEM-West $A$ was conducted aboard the NASA Ames DC-8 research aircraft. Transit and intensive site science missions composed 18 flights, each averaging about 8 hours in duration and covering the altitude range of 0.3 to $12.5 \mathrm{~km}$. The flights over the western Pacific Ocean from which the data for this paper are drawn were centered in the geographic grid bounded by approximately $15^{\circ}-40^{\circ} \mathrm{N}$ latitude and $115^{\circ}-145^{\circ} \mathrm{E}$ longitude. A geographic representation of the study region is shown in Figure 1 . The base of operation for these missions progressed from (1) Yokota, Japan (four missions), to (2) Hong Kong (two missions) and on to (3) Guam (three missions). Data obtained on transit flights between these locations was also utilized in this paper.

The overall scientific rationale and description of the individual aircraft missions are described in the PEM-West A overview paper [Hoell et al., this issue]. The salient features of the largescale meteorological regime are provided by Bachmeier et al. [this issue]. Because we present here a broad description of the observed chemistry in continental outflow air masses during PEMWest $A$, it is impractical to provide the details here for the individual species measurements. Instead, the philosophy was adopted to present measurement-specific details in the PEM-West A overview paper [Hoell et al., this issue]. Additional information for individual species is also summarized in Gregory et al. [this issue], with the details of species-specific measurements contained in numerous companion papers in this issue.

\section{Formulation of Continental Outflow Data Set}

\subsection{Meteorological Basis}

The detailed synoptic meteorological setting leading to outflow of Asian continental air masses over the western Pacific Ocean is described in companion papers [Bachmeier et al., this issue; Merrill, this issue]. In later sections of this paper we present the general chemical characteristics of continental outflow from Asia and Japan that occurred at various altitudes. This section provides a brief description of the large-scale meteorological features.

An extensive subtropical ridge of high pressure was centered over the central western Pacific area near $30^{\circ}-35^{\circ} \mathrm{N}$ and $160^{\circ}$ $170^{\circ} \mathrm{E}$. This high often caused low-altitude easterly flow of aged marine air to persist at Guam and off the eastern coast of Japan. The air masses associated with this flow essentially constitute the chemical classification termed "aged marine" discussed by Gregory et al. [this issue]. Here we contrast the chemistry of "fresh" ( $<5$ days old) outflowing air with that of aged marine $(\geq 10$ days).

A second large anticyclone located over central and eastern China counteracted the marine flow by providing steady north to northwesterly flow of continental air across the Sea of Japan and the East and South China Seas. We sampled this low altitude flow several times during PEM-West $A$, as it was responsible for bringing "fresh continental emissions" out over the coastal western Pacific Ocean.

In the middle to upper troposphere the flow was predominately westerly off the Asian continent, especially north of $30^{\circ}$ latitude. Rapid westerly flow occurred in the $7-$ to $12.5-\mathrm{km}$ altitude region due to the Japan (polar) jet [Merrill et al., 1985; Kritz et al., 1990]. Convective activity over China could potentially inject ground level emissions into this jet region where they would be subjected to rapid transport eastward over Japan and the North Pacific Ocean. A large majority of the constant altitude flight legs in the $2-7$ and $7-12.5 \mathrm{~km}$ regions were influenced by such Asian continental outflow during missions conducted from Japan and Hong Kong.

\subsection{Measurement Database}

Extensive processing of final archived data was required to obtain the data products utilized in our analysis here. Archived data for each species measured in PEM-West $A$ is maintained by 


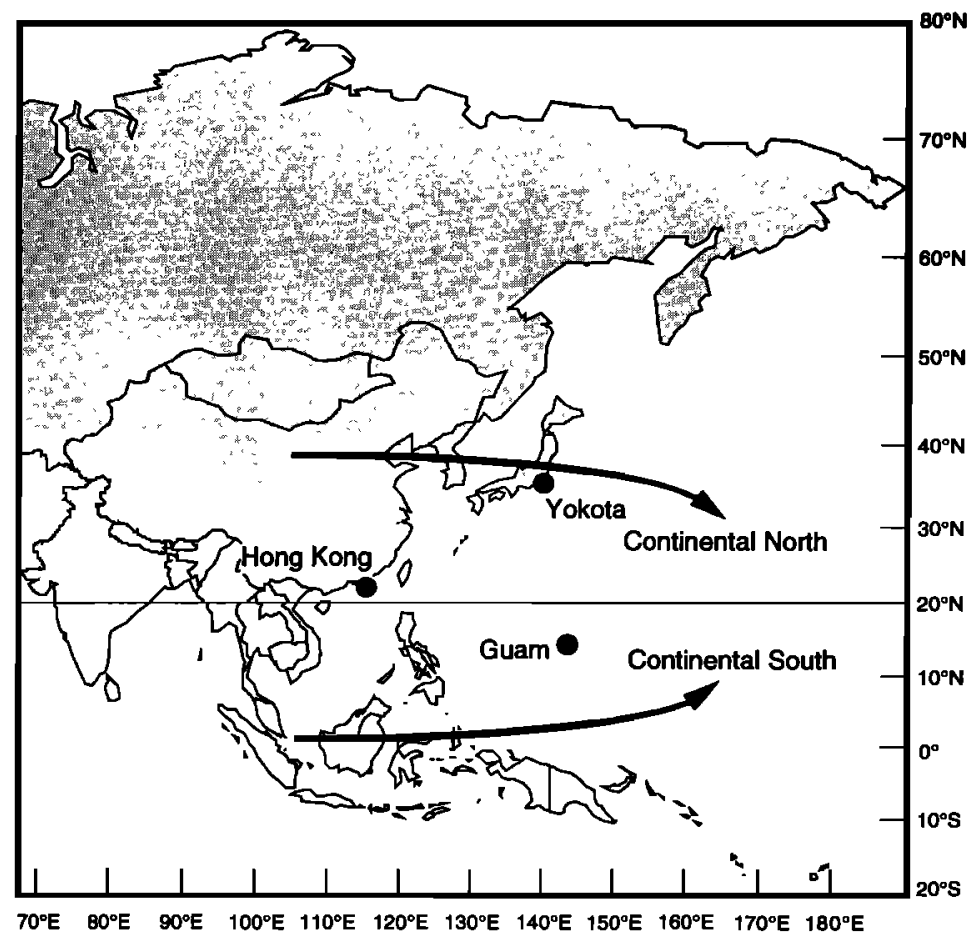

Figure 1. Geographical representation of the PEM-West A study region showing the continental north (CN) and continental south (CS) source areas. The line at $20^{\circ} \mathrm{N}$ denotes the geographic division between the $\mathrm{CN}$ and the CS source regions.

the NASA Global Tropospheric Chemistry project office at Langley Research Center in Hampton, Virginia. Because of extreme diversity in measurement time resolutions for the various species of interest, merged data products were produced for several desired intervals. These data products were generated at the Georgia Institute of Technology (GIT) under the supervision of S. Sandholm and J. Bradshaw. Here we utilized 90-s-averaged data that correspond to the highest-resolution GIT $\mathrm{NO}_{x}$ (NO + $\mathrm{NO}_{2}$ ) and $\mathrm{NO}_{\mathrm{y}}$ (total reactive odd nitrogen) measurements. For consistency, the GIT NO and $\mathrm{NO}_{\mathrm{y}}$ measurements are used in this paper, with the NO data filtered to correspond only to a solar zenith angle of $0^{\circ}-60^{\circ}$. It should be noted that the chemiluminescence NO measurements reported by Kondo et al., [this issue] were indistinguishable from the GIT two-photon laserinduced fluorescence values utilized here. The measurements of faster response instruments (e.g., meteorological parameters and chemical species including $\mathrm{O}_{3}, \mathrm{CO}, \mathrm{CO}_{2}, \mathrm{CH}_{4}$, and $\mathrm{N}_{2} \mathrm{O}$ ) were averaged to correspond to the 90 -s-based time intervals.

Merged data products on various other time resolutions were utilized for species with longer time resolutions (e.g., sulfur gases, acidic gases, peroxides, peroxyacetylnitrate (PAN), hydrocarbons, and aerosol species). The hydrocarbon data used here are from measurements reported by Blake et al., [this issue].

For all species their limit of detection values were utilized for measurement intervals reported as such. For the analysis of continental outflow presented in this paper the mixing ratios of most species were generally well above their stated limits of detection, except for cases where the short-lived hydrocarbons and soluble species were depleted in air masses classified as aged 2 5 days.

\subsection{Classification of Database}

Isentropic back trajectories were utilized to identify time intervals that corresponded to constant altitude flight legs where the sampled air masses had recently passed over continental areas [Merrill, this issue]. Spiral data were not utilized in our analysis due to heterogeneity in air masses and practical limitations imposed by the vertical density of trajectories. The eastern edge of the continental area considered was defined geographically as the Pacific rim arc landmasses composed of Japan, the Peoples's Republic of China, Taiwan, and Indonesia. Examination of the times since the air masses last passed over continental areas revealed that a natural break in groupings occurred around 2 days. Back trajectories indicated that it was unlikely that air masses were sampled with emissions less than $1-1.5$ days old. Thus we compare here the chemical composition of "fresh" ( $<2$ days) with "short-term" aged ( $>2$ but $<5$ days) air masses of continental origin over coastal waters of the western Pacific Ocean.

Data for tropospheric species measured in PEM-West A were classified according to the above scheme and then broken into three altitude regions of $<2,2-7$, and $7-12.5 \mathrm{~km}$. The vertical groupings were purposely kept simple due to the constraint of only using constant altitude data. The $<2-\mathrm{km}$ group essentially represents the marine boundary layer, clearly defined by the vertical distribution of sea-salt aerosol particles [Browell et al., this issue]. The next altitude group of $2-7 \mathrm{~km}$ was selected to provide information on the middle tropospheric region. The final altitude grouping reflects outflow in the upper troposphere.

We further divided the vertical air mass classifications into two groups referred to here as "continental north" (CN) and "continental south" (CS). The back trajectories showed that two basic flow regimes dominated: (1) $>20^{\circ} \mathrm{N}$ latitude the flow originated over central or northern China and (2) $<20^{\circ} \mathrm{N}$ latitude, the flow had various origins, with some over southeastern Asia and others near Indonesia. The line in Figure 1 indicates the $20^{\circ} \mathrm{N}$ division between the $\mathrm{CN}$ and $\mathrm{CS}$ source regions. It is likely that the latitudinal differences in these air mass histories exposed them to various amounts and types of continental emissions which 
should be reflected in their chemical compositions. We therefore compared the chemical characteristics of the $\mathrm{CN}$ and $\mathrm{CS}$ groupings for the altitude regions of $<2,2-7$, and $7-12.5 \mathrm{~km}$. Excellent examples of typical air mass trajectories for the $\mathrm{CN}$ and CS source regions are presented by Merrill [this issue], Gregory et al. [this issue], and Smyth et al. [this issue].

\section{Characterization of Continental Outflow}

\subsection{Chemical Characteristics of <2-Day Transport Cases}

The largest mixing ratios of many chemical species in $\mathrm{CN}$ outflow were observed at $<2 \mathrm{~km}$ altitude (Table 1). It appears that anthropogenic activities in Asia and Japan contributed significantly to the chemical composition of the low-altitude outflow. Mixing ratios of halocarbon compounds such as $\mathrm{CH}_{3} \mathrm{CCl}_{3}$ and $\mathrm{C}_{2} \mathrm{Cl}_{4}$ were significantly enhanced at $<2 \mathrm{~km}$ compared to their values at higher altitudes and in aged marine air [Gregory et al., this issue]. Asian hydrocarbon signatures show that $\mathrm{CH}_{3} \mathrm{CCl}_{3}$ is a particularly good tracer for industrial activities in this region
[Blake et al., this issue]. The concentrated industrial activity along the eastern coast of the People's Republic of China is a likely source of some of the outflow emissions that we sampled [Kato and Akimoto, 1992].

The relatively small mixing ratios of $\mathrm{NO}_{\mathrm{x}}\left(\mathrm{NO}_{\mathrm{x}}=\mathrm{NO}+\mathrm{NO}_{2}\right.$, median $=132 \mathrm{pptv}$ ) in the air masses sampled at low altitude are indicative of photochemical aging of a few days. Many of the air mass trajectories indicated about 1 day of transit time from over source regions in Asia and Japan to where we sampled them [Merrill, this issue]. In addition, the $\mathrm{SO}_{2}$ /non-sea-salt (nss)- $\mathrm{SO}_{4}{ }^{2-}$ ratios (not shown) were less than 1.0 on the average, also suggesting several days of aging since emission inputs to the sampled air masses.

Ratios of $\mathrm{C}_{2} \mathrm{H}_{2} / \mathrm{CO}$ and $\mathrm{C}_{3} \mathrm{H}_{8} / \mathrm{C}_{2} \mathrm{H}_{6}$ can provide useful information on the relative age of air masses [Singh and Zimmerman, 1992]. Air masses over the western Pacific that had undergone significant atmospheric processing from photochemical aging and mixing exhibited $\mathrm{C}_{2} \mathrm{H}_{2} / \mathrm{CO}$ values of $<1.0$ (pptv/ppbv) and $<0.10$ (pptv/pptv) for $\mathrm{C}_{3} \mathrm{H}_{8} / \mathrm{C}_{2} \mathrm{H}_{6}$ [Smyth, this issue]. For air

Table 1. Mixing Ratios of Principal Species Measured in Fresh $(<2$ days) Asian Continental-North Outflow for Isentropic Back-Trajectories Originating $>20^{\circ} \mathrm{N}$ Latitude

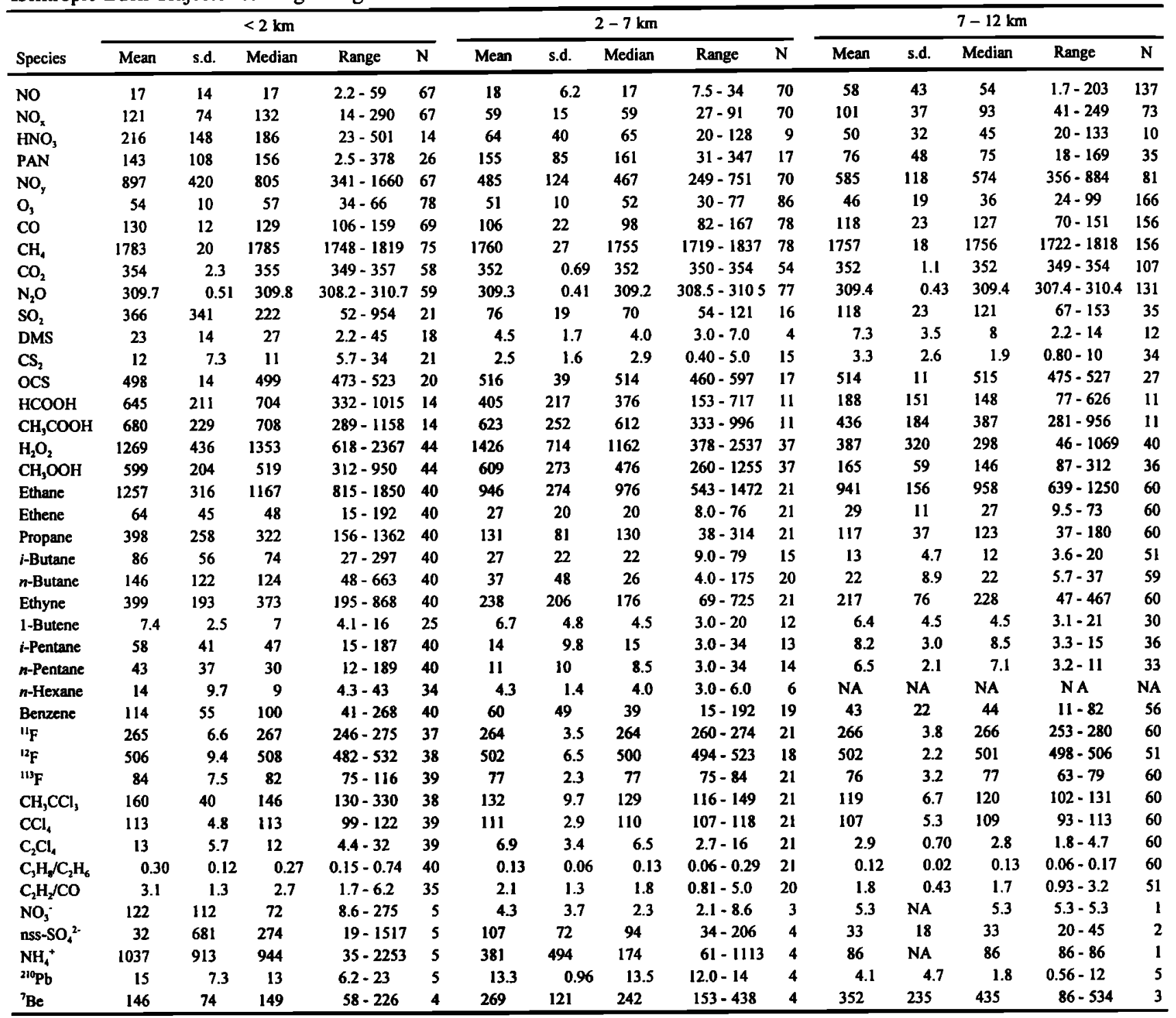

Mixing ratios are stated in parts per trillion by volume; except for $\mathrm{CO}, \mathrm{CH}_{4}, \mathrm{~N}_{2} \mathrm{O}$ and $\mathrm{O}_{3}$ that are in parts per billion by volume; $\mathrm{CO}$ in parts per million by volume, and radioisotopes in femto curies per standard cubic meter. Ratio of $\mathrm{C}_{2} \mathrm{H}_{2} / \mathrm{CO}$ is stated in pptv/ppbv. NA means not available. 
masses originating over the $\mathrm{CN}$ and $\mathrm{CS}$ source regions the ratios were much higher, indicative of relatively fresh emissions to the atmosphere (Tables 1 and 2). Both ratios had their largest values in boundary layer air outflowing from the $\mathrm{CN}$ region (medians of 2.7 for $\mathrm{C}_{2} \mathrm{H}_{2} / \mathrm{CO}$ and 0.27 for $\mathrm{C}_{3} \mathrm{H}_{8} / \mathrm{C}_{2} \mathrm{H}_{6}$ ). Thus these ratios and associated general chemical composition showed that the $\mathrm{CN}$ boundary layer outflow from Asia and Japan contained the freshest emission signatures over the western Pacific. Note that we did not encounter ( $<2$ day) boundary layer outflow from the CS region (Table 2 ).

On the average, values of $\mathrm{C}_{2} \mathrm{H}_{2} / \mathrm{CO}$ and $\mathrm{C}_{3} \mathrm{H}_{8} / \mathrm{C}_{2} \mathrm{H}_{6}$ in air masses in the $2-$ to $12-\mathrm{km}$ altitude range were reasonably constant and about $50 \%$ less than in the $\mathrm{CN}$ boundary layer outflow. The ratios were, however, still significantly elevated compared to aged marine air over the western Pacific Ocean [Gregory et al., this issue; Smyth, this issue].

\subsection{Chemical Characteristics of 2- to 5-Day Transport Cases}

Air masses with transport times of 2 - 5 days since their last landfall were sampled only at $7-12 \mathrm{~km}$ for the $\mathrm{CN}$ cases and in the 2- to 7 and 7- to 12-km altitude ranges for the CS region (Tables 3 and 4). Mixing ratios of most species were very similar in air masses classified as <2- and 2- to 5-day transport cases. This was true even for some of the more reactive hydrocarbon compounds (e.g., ethene). In addition, values of the ratios $\mathrm{C}_{2} \mathrm{H}_{2} / \mathrm{CO}$ and $\mathrm{C}_{3} \mathrm{H}_{8} / \mathrm{H}_{2} \mathrm{H}_{6}$ were not significantly different for the two transport cases. These results emphasize the point that the $<2$ day outflow cases were already aged, perhaps several days, before

Table 2. Mixing Ratios of Principal Species Measured in Fresh ( $<2$ days) Asian Continental-South Outflow for Isentropic Back-Trajectories Originating $<20^{\circ} \mathrm{N}$ Latitude

\begin{tabular}{|c|c|c|c|c|c|c|c|c|c|c|}
\hline \multirow[b]{2}{*}{ Species } & \multicolumn{5}{|c|}{$2-7 \mathrm{~km}$} & \multicolumn{5}{|c|}{$7-12 \mathrm{~km}$} \\
\hline & Mean & s.d. & Median & Range & $\mathrm{N}$ & Mean & s.d. & Median & Range & $\mathbf{N}$ \\
\hline NO & 17 & 31 & 9.4 & $1.7-163$ & 27 & 90 & 51 & 77 & $19-205$ & 74 \\
\hline $\mathrm{NO}_{\mathrm{x}}$ & 44 & 49 & 33 & $17-276$ & 27 & 149 & 59 & 141 & $63-318$ & 74 \\
\hline $\mathrm{HNO}_{3}$ & 68 & 27 & 74 & $32-99$ & 5 & 15 & 9.5 & 14 & $<5-16$ & 13 \\
\hline PAN & 19 & 30 & 8.0 & $2.2-99$ & 10 & 117 & 43 & 111 & $38-232$ & 22 \\
\hline $\mathrm{NO}_{\mathrm{y}}$ & 406 & 133 & 409 & $227-838$ & 27 & 633 & 129 & 609 & $380-939$ & 74 \\
\hline $\mathrm{O}_{3}$ & 24 & 6 & 24 & $15-44$ & 33 & 56 & 9 & 54 & $26-85$ & 129 \\
\hline $\mathrm{CO}$ & 97 & 28 & 93 & $71-216$ & 31 & 104 & 8.9 & 104 & $80-127$ & 125 \\
\hline $\mathrm{CH}_{4}$ & 1723 & 19 & 1718 & $1710-1797$ & 31 & 1794 & 32 & 1802 & $1715-1849$ & 125 \\
\hline $\mathrm{CO}_{2}$ & 353 & 1.1 & 352 & $352-356$ & 24 & 351 & 1.2 & 350 & $349-353$ & 112 \\
\hline $\mathrm{N}_{2} \mathrm{O}$ & 309.3 & 0.24 & 309.3 & $308.7-309.8$ & 31 & 309.6 & 0.37 & 309.6 & $308.2-310.2$ & 124 \\
\hline $\mathrm{SO}_{2}$ & 267 & 572 & 46 & $34-1676$ & 8 & 157 & 45 & 143 & $104-271$ & 26 \\
\hline DMS & 7.0 & 5.7 & 7.0 & $3.0-11.2$ & 2 & 2.5 & 0.58 & 2.5 & $2.1-3.6$ & 4 \\
\hline $\mathrm{CS}_{2}$ & 5.8 & 13 & 0.87 & $0.54-38$ & 8 & 1.6 & 0.93 & 1.2 & $0.57-4.6$ & 27 \\
\hline OCS & 494 & 11 & 491 & $484-516$ & 8 & 475 & 23 & 474 & $397-517$ & 27 \\
\hline $\mathrm{HCOOH}$ & 339 & 143 & 302 & $188-608$ & 6 & 319 & 241 & 280 & $90-1001$ & 13 \\
\hline $\mathrm{CH}_{7} \mathrm{COOH}$ & 511 & 175 & 481 & $280-796$ & 6 & 704 & 423 & 631 & $247-1601$ & 13 \\
\hline $\mathrm{H}_{2} \mathrm{O}_{2}$ & 1813 & 89 & 1824 & $1667-1982$ & 11 & 279 & 122 & 275 & $103-608$ & 33 \\
\hline $\mathrm{CH}_{3} \mathrm{OOH}$ & 818 & 205 & 718 & $670-1245$ & 11 & 110 & 52 & 97 & $52-209$ & 29 \\
\hline Ethane & 514 & 55 & 536 & $437-579$ & 7 & 765 & 103 & 760 & $508-957$ & 28 \\
\hline Ethene & 37 & 36 & 19 & $13-100$ & 7 & 19 & 11 & 16 & $7.7-61$ & 28 \\
\hline Propane & 38 & 10 & 38 & $25-53$ & 7 & 75 & 27 & 69 & $31-172$ & 28 \\
\hline$i$-Butane & 18 & 14 & 12 & $7.3-34$ & 3 & 8.7 & 6.8 & 6.8 & $4.3-33$ & 20 \\
\hline$n$-Butane & 11 & 4.4 & 10 & $6.5-18$ & 7 & 15 & 14 & 10 & $4.3-73$ & 24 \\
\hline Ethyne & 84 & 22 & 81 & $57-124$ & 7 & 181 & 64 & 187 & $63-299$ & 28 \\
\hline 1-Butene & 8.4 & 8.7 & 4.4 & $3.1-25$ & 7 & 5.2 & 3.3 & 4.8 & $3.3-13$ & 9 \\
\hline$i$-Pentane & 8.5 & 1.7 & 9.3 & $6.1-9.8$ & 3 & 8.9 & 7.9 & 4.8 & $3.6-27$ & 10 \\
\hline$n$-Pentane & 4.5 & 2.3 & 4.2 & $3.3-9.7$ & 6 & 6.4 & 4.5 & 4.7 & $3.3-16$ & 9 \\
\hline$n$-Hexane & 9.5 & NA & 9.5 & $9.5-9.5$ & 1 & 3.5 & 0 & 3.5 & $3.5-3.5$ & 2 \\
\hline Benzene & 24 & 7.2 & 21 & $15-37$ & 7 & 31 & 17 & 31 & $6.8-69$ & 27 \\
\hline${ }^{11} F$ & 262 & 2.1 & 263 & $259-264$ & 7 & 265 & 3.5 & 264 & $258-274$ & 27 \\
\hline${ }^{12} \mathrm{~F}$ & 499 & 7.0 & 500 & $489-507$ & 7 & 501 & 4.2 & 502 & $490-511$ & 27 \\
\hline${ }^{113} \mathrm{~F}$ & 77 & 1.2 & 77 & $76-79$ & 7 & 77 & 1.9 & 77 & $72-82$ & 27 \\
\hline $\mathrm{CH}_{3} \mathrm{CCl}_{3}$ & 132 & 11 & 130 & $117-151$ & 7 & 122 & 9 & 126 & $103-141$ & 27 \\
\hline $\mathrm{CCl}_{4}$ & 108 & 2.4 & 109 & $103-110$ & 7 & 109 & 4.0 & 110 & $99-118$ & 27 \\
\hline $\mathrm{C}_{2} \mathrm{Cl}_{4}$ & 3.6 & 0.86 & 3.3 & $2.7-5.1$ & 6 & 3.0 & 0.80 & 3.1 & $1.3-4.3$ & 27 \\
\hline $\mathrm{C}_{3} \mathrm{H}_{8} / \mathrm{C}_{2} \mathrm{H}_{6}$ & 0.08 & 0.02 & 0.08 & $0.05-0.10$ & 7 & 0.15 & 0.22 & 0.09 & $0.03-0.98$ & 28 \\
\hline $\mathrm{C}_{2} \mathrm{H}_{2} / \mathrm{CO}$ & 1.0 & 0.38 & 0.90 & $0.68-1.7$ & 7 & 1.7 & 0.47 & 1.7 & $0.77-2.5$ & 28 \\
\hline $\mathrm{NO}_{3}^{-}$ & $<5$ & NA & NA & N A & 31 & 28 & 13 & 28 & $<5-37$ & 6 \\
\hline nss-SO ${ }_{4}{ }^{2-}$ & $<9$ & NA & NA & NA & 1 & 34 & 22 & 28 & $13-72$ & 6 \\
\hline $\mathrm{NH}_{4}{ }^{+}$ & $<25$ & NA & NA & NA & 1 & 34 & 13 & 34 & $<25-52$ & 6 \\
\hline${ }^{210} \mathrm{~Pb}$ & 0.99 & NA & 0.99 & $0.99-0.99$ & 1 & 6.8 & 2.2 & 7.1 & $4.1-11$ & 7 \\
\hline${ }^{7} \mathrm{Be}$ & 194 & NA & 194 & $194-194$ & 1 & 255 & 190 & 234 & $<10-467$ & 7 \\
\hline
\end{tabular}


Table 3. Mixing Ratios of Principal Species Measured in Aged (2-5 days) Asian Continental-North Outflow for Isentropic Back-Trajectories Originating $>20^{\circ} \mathrm{N}$ Latitude

\begin{tabular}{|c|c|c|c|c|c|}
\hline \multirow[b]{2}{*}{ Species } & \multicolumn{5}{|c|}{$7-12 \mathrm{~km}$} \\
\hline & Mean & s.d. & Median & Range & $\mathbf{N}$ \\
\hline NO & 44 & 60 & 35 & $1.5-358$ & 81 \\
\hline $\mathrm{NO}_{\mathrm{x}}$ & 83 & 19 & 79 & $55-162$ & 53 \\
\hline $\mathrm{HNO}_{3}$ & 36 & 5.7 & 36 & $27-42$ & 5 \\
\hline PAN & 42 & 34 & 30 & $6.9-96$ & 26 \\
\hline $\mathrm{NO}_{\mathrm{y}}$ & 406 & 127 & 364 & $212-640$ & 43 \\
\hline $\mathrm{O}_{3}$ & 39 & 12 & 34 & $25-61$ & 99 \\
\hline $\mathrm{CO}$ & 103 & 16 & 110 & $72-122$ & 84 \\
\hline $\mathrm{CH}_{4}$ & 1736 & 15 & 1730 & $1719-1782$ & 84 \\
\hline $\mathrm{CO}_{2}$ & 352 & 1.1 & 352 & $350-353$ & 63 \\
\hline $\mathrm{N}_{2} \mathrm{O}$ & 309.3 & 0.25 & 309.3 & $308.9-309.9$ & 70 \\
\hline $\mathrm{SO}_{2}$ & 120 & 49 & 98 & $67-216$ & 18 \\
\hline DMS & 37 & 18 & 37 & $7.4-80$ & 16 \\
\hline $\mathrm{CS}_{2}$ & 6.3 & 3.1 & 4.7 & $3.1-12$ & 19 \\
\hline OCS & 509 & 22 & 514 & $438-526$ & 14 \\
\hline $\mathrm{HCOOH}$ & 157 & 52 & 152 & $82-213$ & 5 \\
\hline $\mathrm{CH}_{3} \mathrm{COOH}$ & 308 & 128 & 325 & $115-469$ & 5 \\
\hline $\mathrm{H}_{2} \mathrm{O}_{2}$ & 682 & 433 & 636 & $91-1460$ & 16 \\
\hline $\mathrm{CH}_{3} \mathrm{OOH}$ & 231 & 74 & 213 & $119-359$ & 11 \\
\hline Ethane & 757 & 64 & 783 & $563-828$ & 46 \\
\hline Ethene & 29 & 12 & 26 & $5.3-68$ & 46 \\
\hline Propane & 83 & 20 & 85 & $27-124$ & 46 \\
\hline$i$-Butane & 13 & 5.0 & 13 & $3.2-23$ & 43 \\
\hline$n$-Butane & 24 & 8.1 & 22 & $5.6-40$ & 44 \\
\hline Ethyne & 165 & 26 & 171 & $67-200$ & 46 \\
\hline 1-Butene & 4.7 & 2.2 & 4.6 & $3.4-12$ & 20 \\
\hline$i$-Pentane & 11 & 4.4 & 12 & $3.3-19$ & 41 \\
\hline$n$-Pentane & 9.8 & 3.9 & 10 & $3.5-17$ & 42 \\
\hline$n$-Hexane & 4.4 & 1.8 & 4.9 & $3.1-9.6$ & 10 \\
\hline Benzene & 46 & 17 & 45 & $10-105$ & 44 \\
\hline "IF & 259 & 7.4 & 258 & $248-277$ & 46 \\
\hline${ }^{12} \mathrm{~F}$ & 492 & 2.9 & 494 & $488-494$ & 4 \\
\hline${ }^{113} \mathrm{~F}$ & 75 & 3.4 & 75 & $70-83$ & 46 \\
\hline $\mathrm{CH}_{3} \mathrm{CCl}_{3}$ & 126 & 5.2 & 125 & $113-136$ & 46 \\
\hline $\mathrm{CCl}_{4}$ & 108 & 3.2 & 108 & $104-116$ & 46 \\
\hline $\mathrm{C}_{2} \mathrm{Cl}_{4}$ & 3.2 & 0.62 & 3.1 & $2.6-4.9$ & 46 \\
\hline $\mathrm{C}_{3} \mathrm{H}_{8} / \mathrm{C}_{2} \mathrm{H}_{6}$ & 0.11 & 0.02 & 0.11 & $0.04-0.15$ & 46 \\
\hline $\mathrm{C}_{2} \mathrm{H}_{2} / \mathrm{CO}$ & 1.5 & 0.15 & 1.5 & $0.84-1.7$ & 37 \\
\hline $\mathrm{NO}_{3}$ & 40 & 34 & 37 & $6.4-81$ & 4 \\
\hline nss-SO ${ }_{4}^{2-}$ & 40 & 23 & 39 & $15-66$ & 4 \\
\hline $\mathrm{NH}_{4}^{+}$ & 43 & 11 & 41 & $33-55$ & 3 \\
\hline${ }^{210} \mathrm{~Pb}$ & 4.5 & 3.6 & 4.4 & $0.51-8.7$ & 4 \\
\hline${ }^{7} \mathrm{Be}$ & 91 & 42 & 74 & $63-152$ & 4 \\
\hline
\end{tabular}

we sampled them. It appears that much of the outflowing air had already undergone significant atmospheric processing before we intercepted it over the coastal western Pacific Ocean.

\subsection{Vertical Distribution}

Plots of species vertical distribution shown in this section are organized into three categories: (1) principal species emitted from combustion processes, (2) water-soluble species, and (3) biogenic or air mass tracer species. The vertical distribution of selected species in $\mathrm{CN}$ air masses with transport times of $<2$ days is shown in Figures $2 \mathrm{a}, 2 \mathrm{~b}$, and $2 \mathrm{c}$. These plots illustrate some interesting characteristics of the continental outflow. The CO data, for example, indicate a probable combustion influence on the chemistry below $4 \mathrm{~km}$ and above $10 \mathrm{~km}$ altitudes (Figure 2a). The median $\mathrm{CO}$ mixing ratio in the upper troposphere and in the boundary layer were essentially equal at $\mathbf{1 3 0}$ parts per billion by volume (ppbv) (Table 1). There also appeared to be an altitude region between 4 and $8 \mathrm{~km}$ containing cleaner air masses with mixing ratios of $\mathrm{CO} \approx 100 \mathrm{ppbv}$.

These values of $\mathrm{CO}$ are very similar to the ones determined in November 1981 by a gas filter radiometer operating in the experiment "Measurement of Air Pollution from Satellites" (MAPS) flown on the NASA space shuttle [Newell et al., 1988]. Over China the MAPS instrument recorded $\mathrm{CO}$ mixing ratios as large as $115 \mathrm{ppbv}$ with an average of $102 \mathrm{ppbv}$. Since the MAPS instrument responds to $\mathrm{CO}$ in the middle to upper troposphere, it was concluded by Newell et al. [1988] that this $\mathrm{CO}$ was derived from surface sources and brought to higher altitudes by active convection or large-scale rising motions. Vertical transport of $\mathrm{CO}$ from the boundary layer to $9 \mathrm{~km}$ altitude by convective systems has also been reported over North America [Kleinman and Daum, 1991]. The PEM-West A experiment was conducted in the fall time period, when the meteorological regime over China was dominated by cyclonic activity [Bachmeier et al., this issue]. Thus it is likely that vertical transport was quite active over Asian continental source regions.

In the $\mathrm{CN}$ air masses the $\mathrm{NO}_{\mathrm{x}}$ vertical distribution was very similar to that of $\mathrm{CO}$, but in this case the enhanced mixing ratios above $10 \mathrm{~km}$ could either be due to combustion emissions or other source inputs such as from the stratosphere [Liu et al., this issue]. Interestingly, there was no significant enhancement of $\mathrm{NO}_{\mathrm{y}}$ above $10 \mathrm{~km}$ and, in fact, PAN exhibited its smallest mixing ratio values there ( $<50$ parts per trillion by volume (pptv)). The $\mathrm{O}_{3}$ and aerosol distributions also showed low concentrations in this altitude region [Browell et al., this issue]. These decreased vertical trends in PAN and $\mathrm{O}_{3}$ suggest a limited photochemical influence on the chemistry at high altitude.

The middle tropospheric data appear to show chemical characteristics that indicate a ground level source over Asia. Near $9 \mathrm{~km}$ altitude, there appears to be significant outflow of ${ }^{210} \mathrm{~Pb}$, PAN, and $\mathrm{O}_{3}$ that are likely to be of Asian continental origin [Dibb et al., this issue]. The relatively small mixing ratios of water-soluble species (i.e., $\mathrm{HCOOH}, \mathrm{CH}_{3} \mathrm{COOH}, \mathrm{HNO}_{3}, \mathrm{H}_{2} \mathrm{O}_{2}$, $\mathrm{CH}_{3} \mathrm{OOH}$, and $\mathrm{SO}_{2}$ ) at $9 \mathrm{~km}$ altitude suggests that the outflowing materials were transported to this height by wet convective activity over Asia (Figure 2b). The strong correlation with ${ }^{210} \mathrm{~Pb}$ but not ${ }^{7} \mathrm{Be}$ indicates that the elevated mixing ratios of $\mathrm{O}_{3}$ at $9 \mathrm{~km}$ altitude may have originated from a photochemical rather than a stratospheric source [Dibb et al., this issue]. However, significant photochemical production of other species such as the carboxylic acids in the upper troposphere would seem unlikely, based on the $\mathrm{O}_{3}$ and PAN vertical distributions. The ratio $\mathrm{HCOOH} / \mathrm{CH}_{3} \mathrm{COOH}$ exhibited decreased values with increased altitude (Table 1), indicative of a combustion influence in the upper troposphere [Talbot et al., 1988].

Outflow below $5 \mathrm{~km}$ altitude contained clear signals of industrial contamination, as evidenced by enhanced mixing ratios of the tracer species $\mathrm{C}_{2} \mathrm{Cl}_{4}$ (Figure 2c). In the middle to upper troposphere, mixing ratios of $\mathrm{C}_{2} \mathrm{Cl}_{4}$ were near values typical of aged marine air [Gregory et al., this issue]. This observation suggests that the air masses sampled in the boundary layer and at high altitude might have different source regions.

Examination of the vertical distribution of biogenic tracer species can facilitate the interpretation of air mass sources. In Figure $2 \mathrm{c}$ we show plots of $\mathrm{CO}_{2}, \mathrm{CH}_{4}$, and OCS. Although these species are ambiguous biogenic tracers, their vertical distributions indicate some possible scenarios. Carbon dioxide mixing ratios 
Table 4. Mixing Ratios of Principal Species Measured in Aged (2-5 days) Asian Continental-South Outflow for Isentropic Back-Trajectories Originating $<20^{\circ} \mathrm{N}$ Latitude

\begin{tabular}{|c|c|c|c|c|c|c|c|c|c|c|}
\hline \multirow[b]{2}{*}{ Species } & \multicolumn{5}{|c|}{$2-7 \mathrm{~km}$} & \multicolumn{5}{|c|}{$7-12 \mathrm{~km}$} \\
\hline & Mean & s.d. & Median & Range & $\mathbf{N}$ & Mean & s.d. & Median & Range & $\mathbf{N}$ \\
\hline NO & 5.8 & 4.3 & 5.2 & $1.5-23$ & 57 & 4.4 & 2.5 & 3.1 & $2.1-8.5$ & 17 \\
\hline $\mathrm{NO}_{\mathrm{x}}$ & 34 & 13 & 32 & $18-71$ & 49 & 49 & 4.8 & 48 & $42-60$ & 17 \\
\hline $\mathrm{HNO}_{3}$ & 60 & 34 & 67 & $<5.0-95$ & 9 & 5 & NA & 5 & $5-5$ & 1 \\
\hline PAN & 16 & 7.3 & 18 & $2.5-24$ & 14 & NA & NA & NA & NA & NA \\
\hline $\mathrm{NO}_{\mathrm{y}}$ & 193 & 55 & 180 & $123-363$ & 39 & NA & NA & NA & NA & NA \\
\hline $\mathrm{O}_{3}$ & 29 & 9.1 & 26 & $20-72$ & 94 & 30 & 1.3 & 30 & $28-32$ & 19 \\
\hline $\mathrm{CO}$ & 95 & 13 & 101 & $67-108$ & 90 & 109 & 0.98 & 109 & $107-111$ & 18 \\
\hline $\mathrm{CH}_{4}$ & 1717 & 9.5 & 1716 & $1702-1749$ & 90 & 1709 & 4.4 & 1707 & $1704-1721$ & 18 \\
\hline $\mathrm{CO}_{2}$ & 353 & 0.38 & 353 & $352-353$ & 71 & 353 & 0.05 & 353 & $353-353$ & 18 \\
\hline $\mathrm{N}_{2} \mathrm{O}$ & 309.1 & 0.13 & 309.1 & $308.9-309.5$ & 61 & 309.0 & 0.14 & 309.0 & $308.7-309.2$ & 17 \\
\hline $\mathrm{SO}_{2}$ & 50 & 12 & 49 & $34-105$ & 30 & 81 & 2.1 & 81 & $77-83$ & 6 \\
\hline DMS & 4.1 & 1.3 & 4.3 & $2.6-6.7$ & 11 & $<1$ & NA & $<1$ & $<1-<1$ & 5 \\
\hline $\mathrm{CS}_{2}$ & 1.8 & 1.4 & 1.1 & $0.65-4.8$ & 30 & 0.84 & 0.05 & 0.84 & $0.81-0.95$ & 5 \\
\hline OCS & 503 & 5.5 & 502 & $496-516$ & 27 & 505 & 2.8 & 504 & $502-508$ & 5 \\
\hline $\mathrm{HCOOH}$ & 149 & 50 & 147 & $78-244$ & 9 & 90 & NA & 90 & $90-90$ & 1 \\
\hline $\mathrm{CH}_{3} \mathrm{COOH}$ & 226 & 99 & 203 & $120-413$ & 9 & 248 & NA & 248 & $248-248$ & 1 \\
\hline $\mathrm{H}_{2} \mathrm{O}_{2}$ & 1116 & 424 & 973 & $783-2498$ & 20 & NA & NA & NA & NA & NA \\
\hline $\mathrm{CH}_{3} \mathrm{OOH}$ & 722 & 316 & 548 & $384-1261$ & 20 & NA & NA & NA & NA & NA \\
\hline Ethane & 568 & 114 & 625 & $350-668$ & 16 & 664 & 23 & 652 & $650-690$ & 3 \\
\hline Ethene & 11 & 6.6 & 8.5 & $5.3-27$ & 16 & 9.5 & 4.4 & 7.7 & $6.2-14$ & 3 \\
\hline Propane & 29 & 11 & 34 & $9.3-43$ & 16 & 38 & 0.58 & 38 & $37-38$ & 3 \\
\hline$i$-Butane & $<2$ & NA & $<2$ & $<2-4.5$ & 16 & $<2$ & NA & $<2$ & $<2-<2$ & 3 \\
\hline$n$-Butane & $<2$ & NA & $<2$ & $<2-5.3$ & 16 & $<2$ & NA & $<2$ & $<2-<2$ & 3 \\
\hline Ethyne & 78 & 28 & 92 & $29-101$ & 16 & 101 & 2.1 & 100 & $99-103$ & 3 \\
\hline 1-Butene & $<2$ & NA & $<2$ & $<2-7.5$ & 16 & $<2$ & NA & $<2$ & $<2-<2$ & 3 \\
\hline$i$-Pentane & $<2$ & NA & $<2$ & $<2-<2$ & 16 & $<2$ & NA & $<2$ & $<2-<2$ & 3 \\
\hline$n$-Pentane & $<2$ & NA & $<2$ & $<2-<2$ & 16 & $<2$ & NA & $<2$ & $<2-<2$ & 3 \\
\hline$n$-Hexane & $<2$ & NA & $<2$ & $<2-<2$ & 16 & $<2$ & NA & $<2$ & $<2-<2$ & 3 \\
\hline Benzene & 26 & 13 & 26 & $7.5-65$ & 16 & 31 & 5.9 & 29 & $27-38$ & 3 \\
\hline$" \mathrm{~F}$ & 263 & 4.2 & 265 & $250-268$ & 16 & 261 & 0 & 261 & $261-261$ & 3 \\
\hline${ }^{12} \mathrm{~F}$ & 503 & 6.3 & 502 & $494-518$ & 16 & 494 & 0.57 & 495 & $494-495$ & 3 \\
\hline${ }^{113} \mathrm{~F}$ & 76 & 1.7 & 77 & $70-77$ & 16 & 76 & 0.35 & 76 & $76-77$ & 3 \\
\hline $\mathrm{CH}_{3} \mathrm{CCl}_{3}$ & 122 & 6.1 & 124 & $110-131$ & 16 & 128 & 4.5 & 128 & $123-132$ & 3 \\
\hline $\mathrm{CCl}_{4}$ & 108 & 2.7 & 108 & $100-112$ & 16 & 110 & 0.52 & 110 & $109-110$ & 3 \\
\hline $\mathrm{C}_{2} \mathrm{Cl}_{4}$ & 2.5 & 0.34 & 2.6 & $2.1-3.2$ & 16 & 2.6 & 0.21 & 2.6 & $2.4-2.7$ & 3 \\
\hline $\mathrm{C}_{3} \mathrm{H}_{8} / \mathrm{C}_{2} \mathrm{H}_{6}$ & 0.05 & 0.01 & 0.05 & $0.02-0.07$ & 16 & 0.06 & 0.002 & 0.06 & $0.06-0.06$ & 3 \\
\hline $\mathrm{C}_{2} \mathrm{H}_{2} / \mathrm{CO}$ & 0.81 & 0.22 & 0.90 & $0.43-0.98$ & 15 & 0.93 & 0.03 & 0.92 & $0.91-0.96$ & 3 \\
\hline $\mathrm{NO}_{3}^{-}$ & 7.5 & 5.5 & 7.5 & $<5.0-13$ & 3 & 34 & NA & 34 & $34-34$ & 1 \\
\hline $\mathrm{nss}-\mathrm{SO}_{4}{ }^{2-}$ & 30 & 16 & 38 & $12-40$ & 3 & 15 & NA & 15 & $15-15$ & 1 \\
\hline $\mathrm{NH}_{4}^{+}$ & 49 & 28 & 49 & $<25-69$ & 3 & 27 & NA & 27 & $27-27$ & 1 \\
\hline${ }^{210} \mathrm{~Pb}$ & 3.1 & 2.9 & 1.6 & $1.3-6.4$ & 3 & 1.6 & NA & 1.6 & $1.6-1.6$ & 1 \\
\hline${ }^{7} \mathrm{Be}$ & 193 & 72 & 190 & $123-267$ & 3 & $<10$ & NA & $<10$ & $<10-<10$ & 7 \\
\hline
\end{tabular}

were centered around 352 parts per million by volume (ppmv), with a likely anthropogenic enhancement in the boundary layer. From 2 to $9 \mathrm{~km}$ altitude, decreased values of $\mathrm{CO}_{2}$ probably reflect its uptake by the biosphere and suggest that these air masses had recent inputs of near-surface air. The relatively large values of $\mathrm{C}_{2} \mathrm{H}_{2} / \mathrm{CO}$ and $\mathrm{C}_{3} \mathrm{H}_{8} / \mathrm{C}_{2} \mathrm{H}_{6}$ at all altitudes lend further support to the idea that these air masses had recently acquired inputs from surface sources.

One could argue that the values of OCS below about 520 pptv are indicative of biogenic or soil uptake of this species [Chin and Davis, 1993]. The situation is a bit more complicated for $\mathrm{CH}_{4}$, where various ecosystems can either be a source or a sink of it. In addition, $\mathrm{CH}_{4}$ has clear anthropogenic signals from various combustion and waste treatment processes [Harriss et al., 1994].
Undoubtedly, a combination of source/sink relationships have produced the complex $\mathrm{CH}_{4}$ distribution shown in Figure 2c [Matsueda et al., 1993].

For comparison to the $\mathrm{CN}$ data, the vertical distribution of the same ensemble of species in CS air masses with transit times of $<2$ days is depicted in Figures 3a, 3b, and 3c. Here we find a picture not significantly different from the $\mathrm{CN}$ case. Mixing ratios of $\mathrm{CO}$ were moderately elevated in the upper troposphere (100 120 ppbv) but not so much as in the $\mathrm{CN}$ air masses (120 - 160 ppbv). Very similar mixing ratios of $\mathrm{NO}_{x}, \mathrm{PAN}, \mathrm{NO}_{y}$, and $\mathrm{O}_{3}$ were observed in the middle and upper troposphere in both air mass classifications.

Although the data for the CS case were sparse, the vertical distribution of water-soluble species (Figure $3 \mathrm{~b}$ ) was similar to 
$2 a$
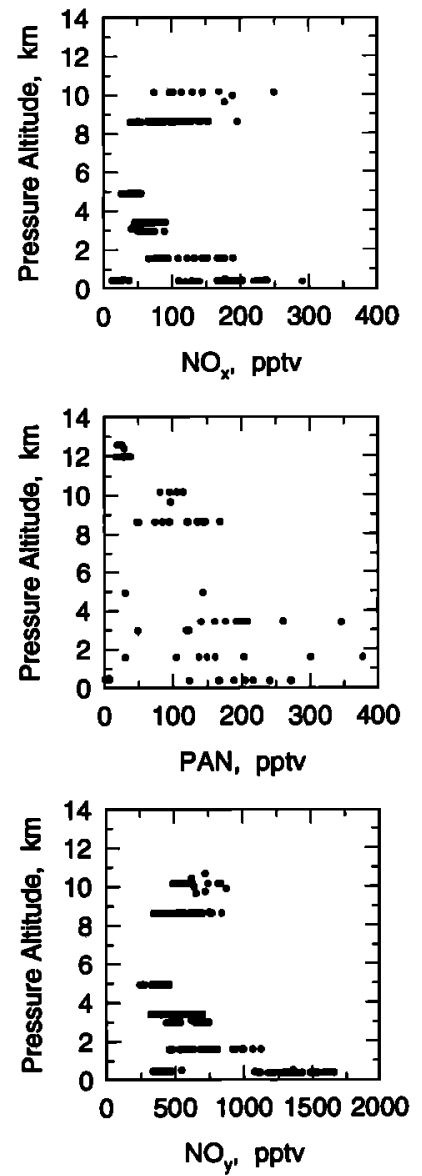

2c
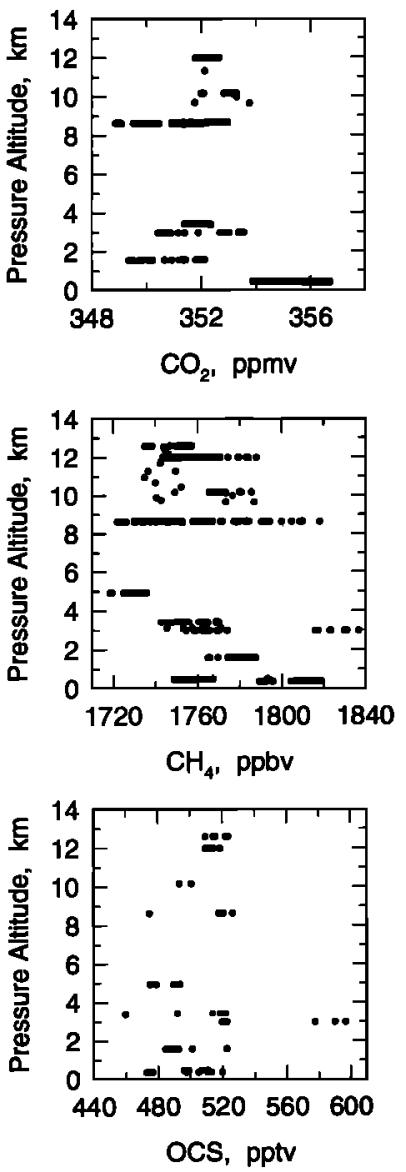
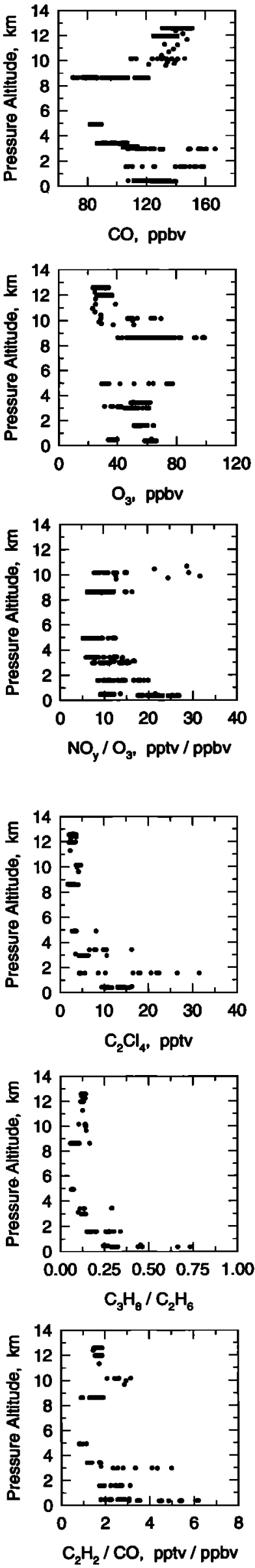

$2 b$
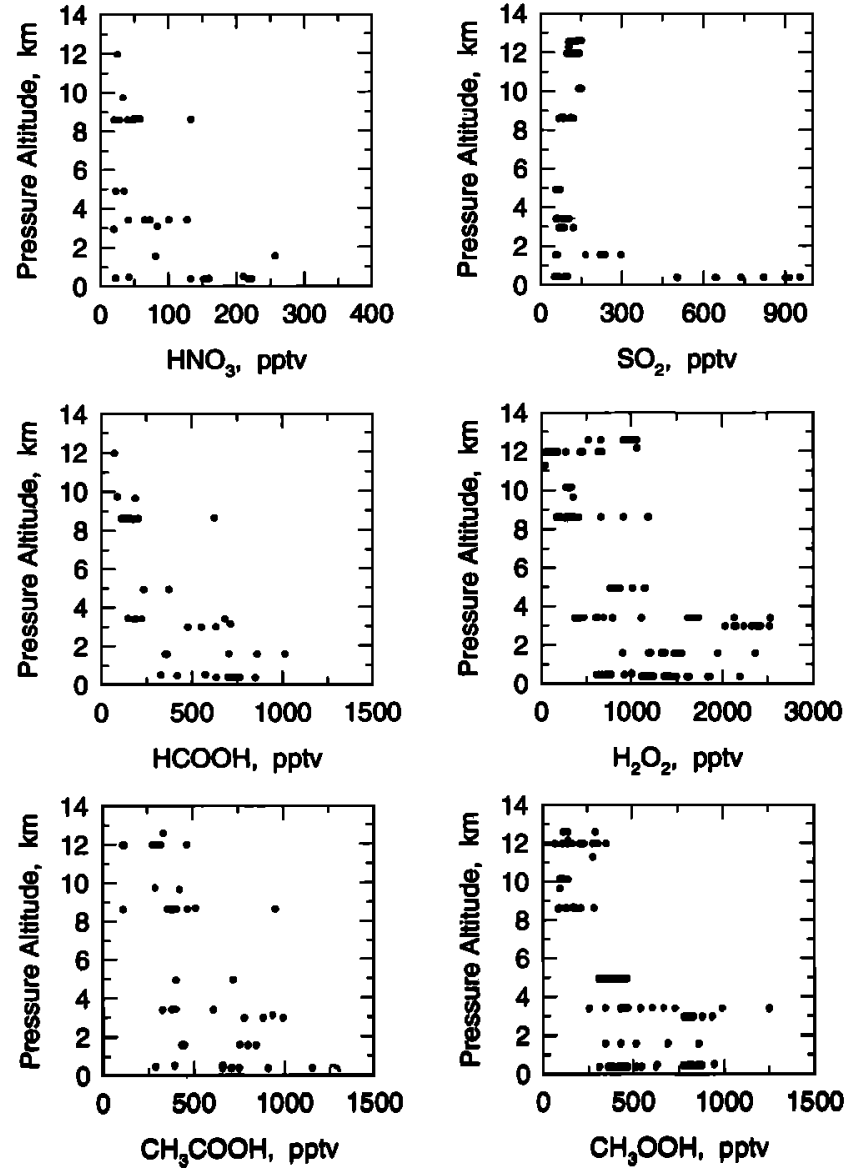

that of the $\mathrm{CN}$ case. Decreased mixing ratios were again found in the upper troposphere, presumably reflecting a principal source at ground level and washout during transport to the upper troposphere. Some exception to this trend was observed for $\mathrm{HCOOH}$ and $\mathrm{CH}_{3} \mathrm{COOH}$, where they occasionally showed relatively large mixing ratios in the middle troposphere indicative of ground level emissions or photochemical sources.

The biogenic tracer compounds shown in Figure 3c illustrate the same basic regime described for the $\mathrm{CN}$ case. It appears that the biogenic source/sink relationships are accentuated in the upper troposphere for the $\mathrm{CS}$ data. We observed mixing ratios of $\mathrm{CO}_{2}$ generally $<352 \mathrm{ppmv}, \mathrm{CH}_{4}$ up to $1840 \mathrm{ppbv}$, and OCS as low as 445 pptv (Figure 3c). These data indicate potential biogenic uptake of $\mathrm{CO}_{2}$ and OCS [Chin and Davis, 1993] and emission of $\mathrm{CH}_{4}$ from Southeast Asia ecosystems [Bachelet and Neue, 1993]. These results would normally be expected in the boundary layer; the surprise is that we observed this at high altitude. These results reemphasize the point that the air masses sampled in the free troposphere appear to have significant recent inputs from ground level sources. In fact, the large values of the ratio $\mathrm{C}_{3} \mathrm{H}_{8} / \mathrm{C}_{2} \mathrm{H}_{6}$ at 8$10 \mathrm{~km}$ altitude indicate very recent communication with surface sources.

Figure 2. Vertical distribution of selected atmospheric species in outflow air masses originating over the continental north source region. Trajectory analysis [Merrill, this issue] indicated that these air masses have spent $\leq 2$ days over the western Pacific Ocean since leaving the Asian continent. Species groupings reflect (a) principal species resulting from combustion processes, (b) watersoluble species, and (c) biogenic or air mass tracer species. 
$3 \mathbf{a}$


3c
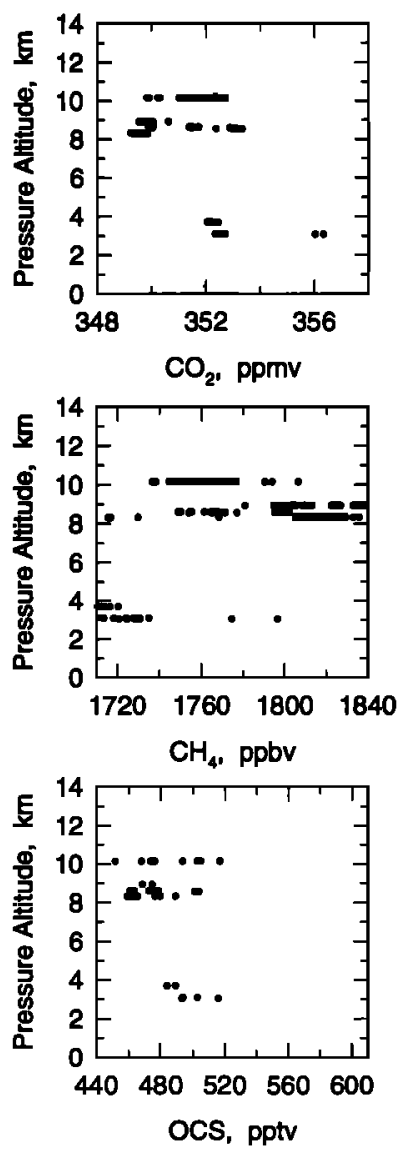

3b
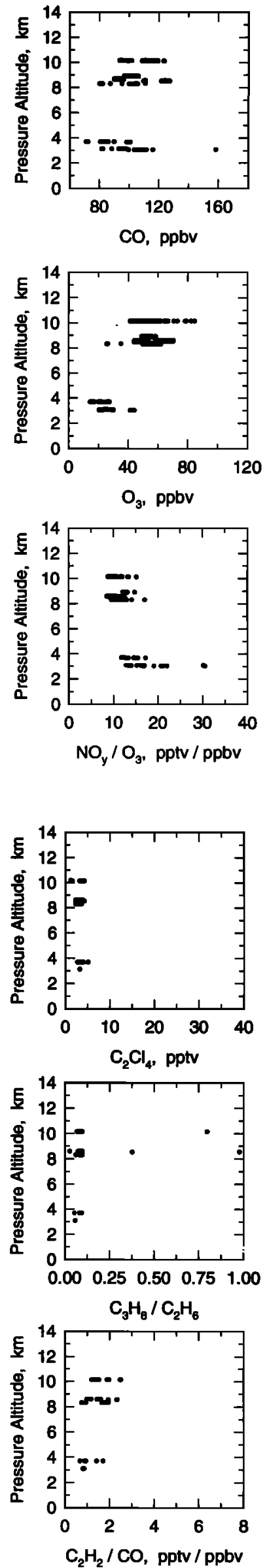
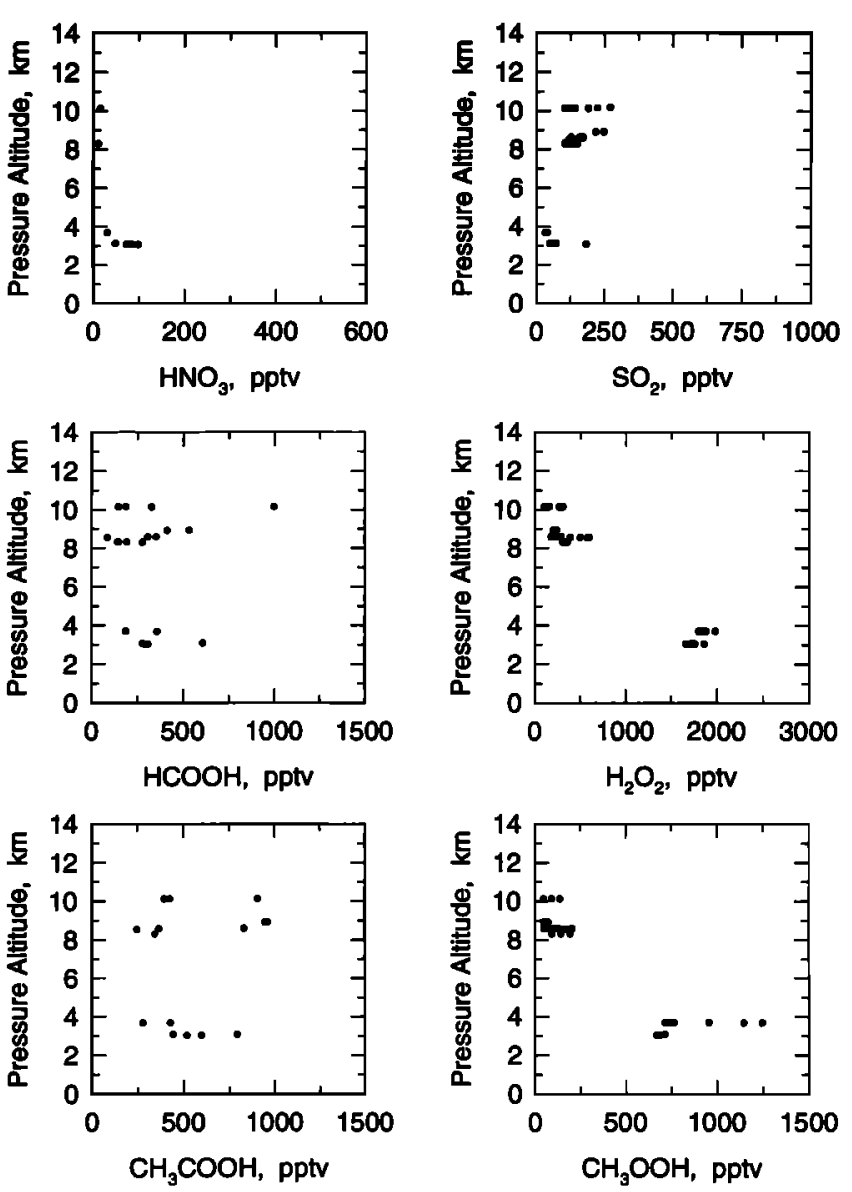

Air masses originating from over both the $\mathrm{CN}$ and $\mathrm{CS}$ source regions exhibited $\mathrm{NO}_{4} / \mathrm{O}_{3}$ ratios centered around 10 (pptv/ppbv). These values are similar to average values reported for the lower to middle troposphere over the eastern Pacific Ocean $(\approx 7)$ [Hübler et al., 1992], in the Arctic ( $\approx$ 9) [Sandholm et al., 1992] and over North America ( $\approx$ 5) [Talbot et al., 1994], and elsewhere in the upper troposphere $(\approx 10)$ [Murphy et al., 1993]. The largest values of $\mathrm{NO}_{\mathrm{y}} / \mathrm{O}_{3}$ observed in the PEM-West A study region $(\approx 30)$ were found in "fresh" continental outflow in the boundary layer before deposition processes significantly removed $\mathrm{NO}_{\mathrm{y}}$ species from the atmosphere (Figures $2 \mathrm{a}$ and $3 \mathrm{a}$ ). In more aged ( $>5$ days) air masses over the western Pacific the ratio $\mathrm{NO}_{\mathrm{y}} / \mathrm{O}_{3}$ had values ranging from 3 to 15 [Smyth et al., this issue]. It appears that the ubiquitous correlation of $\mathrm{NO}_{\mathrm{y}}$ and $\mathrm{O}_{3}$ in the northern hemisphere troposphere is caused by a combination of photochemical loss processes and dilution effects from mixing "polluted" with "clean" air [Sandholm et al., 1994].

Examination of selected species in $\mathrm{CN}$ and $\mathrm{CS}$ air masses with 2- to 5-day transit times from land showed results similar to the $<2$-day cases. These data indicate that the air masses at high altitude had combustion signatures, but they contained little evidence for industrial sources (Figures 4 and 5). For example, mixing ratios of $\mathrm{CO}$ were as large as $120 \mathrm{ppbv}$, while those of $\mathrm{C}_{2} \mathrm{Cl}_{4}$ stayed in the range of $2-3 \mathrm{pptv}$. Ethane and $\mathrm{CO}_{2}$ exhibited trends similar to $\mathrm{CO}$, supporting the idea of potential combustion inputs. The ratios $\mathrm{C}_{2} \mathrm{H}_{2} / \mathrm{CO}$ and $\mathrm{C}_{3} \mathrm{H}_{8} / \mathrm{C}_{2} \mathrm{H}_{6}$ had their largest values at the highest altitudes sampled, adding more support to a

Figure 3. Same as Figure 2 except that no data were obtained in the boundary layer for this trajectory classification. 

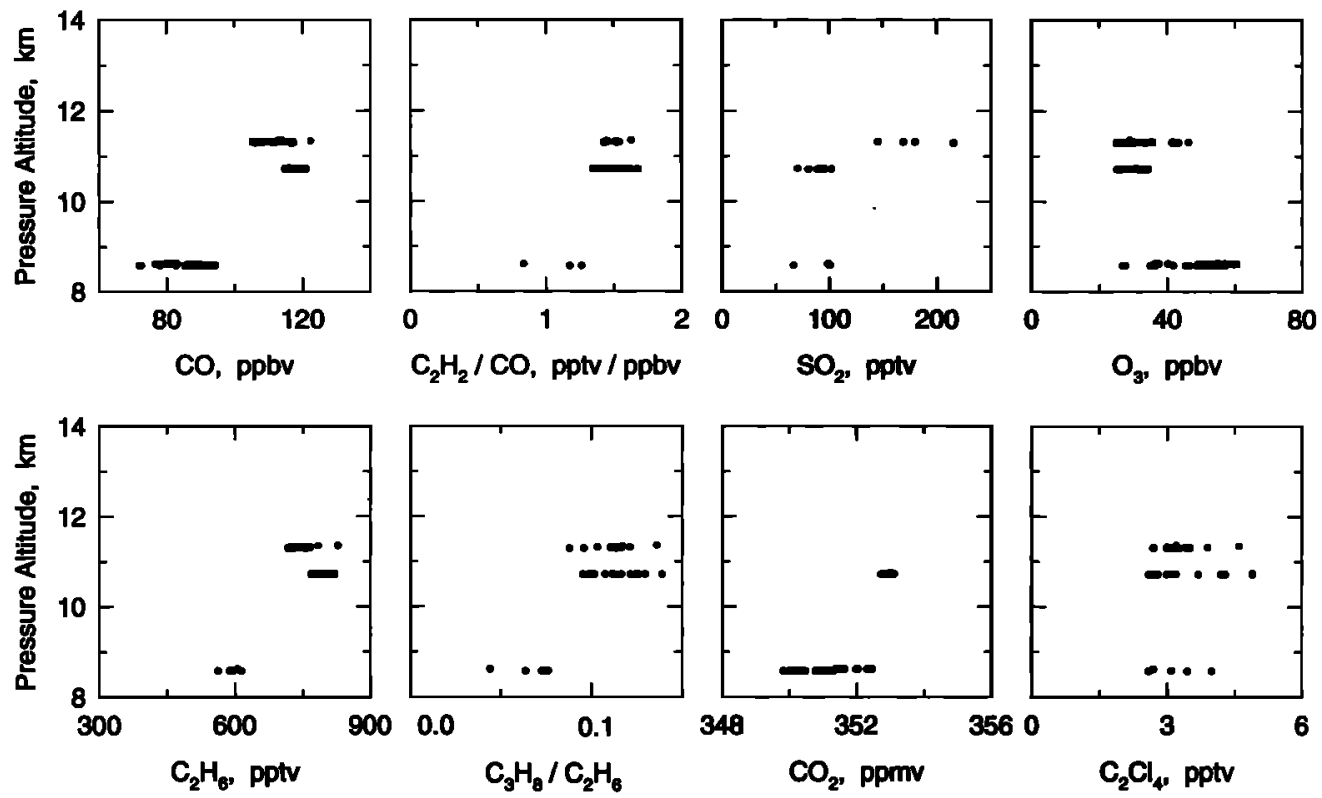

Figure 4. Distribution of selected atmospheric species in the middle to upper troposphere in outflow air masses originating over the continental north source region. Trajectory analysis [Merrill, this issue] indicated that these air masses have spent 2 - 5 days over the western Pacific Ocean since passing over the Asian continent.

scenario of ground level emissions recently influencing this region. Sulfur dioxide also tended to have its largest mixing ratios coincident with those in $\mathrm{CO}$, but here we cannot rule out the possibility of stratospheric inputs of Mount Pinatubo sulfur [ $\mathrm{Liu}$ et al., this issue]. The mixing ratios of $\mathrm{O}_{3}$ and activities of ${ }^{7} \mathrm{Be}$, however, were rather low at high altitude $(\approx 40 \mathrm{ppbv}$ and a few hundred $\mathrm{fCi} \mathrm{scm}{ }^{-1}$, respectively), indicating a weak stratospheric influence on the chemistry there [Dibb et al., this issue].

\subsection{Chemical Source Signature of Pacific Rim Region}

It is desirable to derive a qualitative description of the atmospheric chemical signature derived from the Pacific rim region. We did this for various species by subtracting their median mixing ratio in the free tropospheric $\mathrm{CN}$ and CS cases (2 $-12 \mathrm{~km}$ altitude) from their median value in aged ( $>10$ days since landfall) marine air [Gregory et al., this issue]. The results of these calculations (delta $\mathrm{CN}$ and $\mathrm{CS}$ ) are presented in Table 5. Obviously, these calculations do not accurately portray the potential sources of short-lived species over the Pacific rim region.

This comparison showed significant enrichment of the trace gases $\mathrm{NO}_{y} \mathrm{O}_{3}, \mathrm{CO}, \mathrm{CH}_{4}, \mathrm{SO}_{2}, \mathrm{HCOOH}, \mathrm{H}_{2} \mathrm{O}_{2}, \mathrm{C}_{2} \mathrm{H}_{6}, \mathrm{C}_{3} \mathrm{H}_{8}, \mathrm{C}_{2} \mathrm{H}_{2}$, F-12, plus aerosol $\mathrm{NH}_{4}^{+}$and ${ }^{210} \mathrm{~Pb}$ in the Asian continental outflow (Table 5). Modest enhancements are also apparent for several other species, particularly in air masses derived from the $\mathrm{CN}$ source region. Clearly, combustion and related photochemical
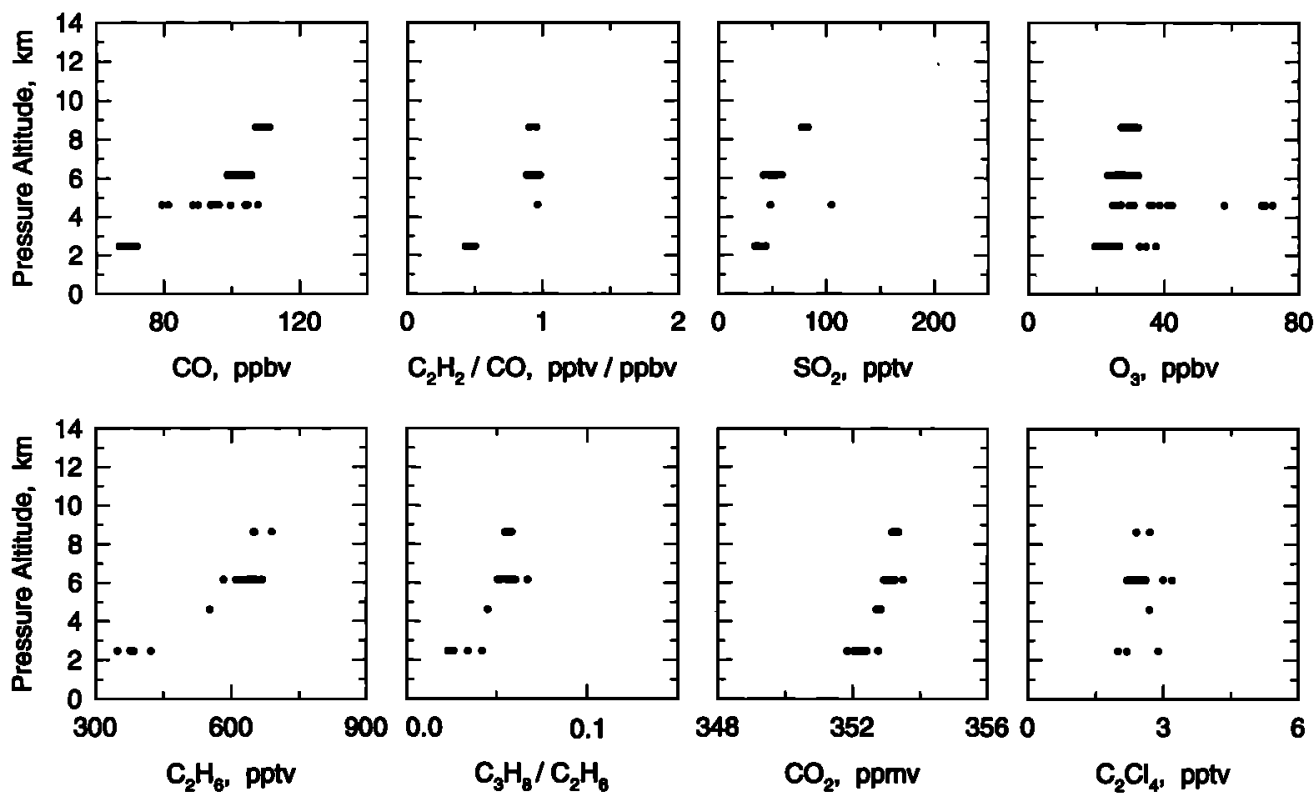

Figure 5. Same as Figure 4. 
Table 5. Comparison of Principal Species in Asian Continental-North (CN) and Continental-South (CS) Outflow in the Altitude Range of 2-12 km

\begin{tabular}{|c|c|c|c|c|c|c|}
\hline \multirow[b]{2}{*}{ Species } & \multicolumn{2}{|c|}{$\mathrm{CN}$} & \multicolumn{2}{|c|}{$\mathrm{CS}$} & \multirow[b]{2}{*}{$\triangle \mathrm{CN}$} & \multirow[b]{2}{*}{$\triangle \mathrm{CS}$} \\
\hline & Median & $\pm 95 \%$ C.l. & Median & $\pm 95 \%$ C.I. & & \\
\hline NO & 44 & 5.5 & 71 & 11 & $32 *$ & $59^{*}$ \\
\hline $\mathrm{NO}_{\mathrm{x}}$ & 80 & 5.8 & 121 & 15 & $40^{*}$ & $81^{*}$ \\
\hline $\mathrm{HNO}_{3}$ & 56 & 17 & 53 & 32 & $39 *$ & $36^{*}$ \\
\hline PAN & 102 & 20 & 86 & 22 & $88 *$ & $72^{*}$ \\
\hline $\mathrm{NO}_{\mathrm{y}}$ & 539 & 21 & 572 & 33 & $428^{*}$ & $461^{*}$ \\
\hline $\mathrm{O}_{3}$ & 48 & 2.0 & 50 & 2.4 & $25^{*}$ & $27^{*}$ \\
\hline $\mathrm{CO}$ & 114 & 3.0 & 102 & 2.4 & $37^{*}$ & $25^{*}$ \\
\hline $\mathrm{CH}_{4}$ & 1758 & 2.8 & 1780 & 6.5 & $67^{*}$ & $89 *$ \\
\hline $\mathrm{CO}_{2}$ & 352 & 0.15 & 351 & 0.24 & $-1.0^{*}$ & $-2.0^{*}$ \\
\hline $\mathrm{N}_{2} \mathrm{O}$ & 309.3 & 0.06 & 309.5 & 0.06 & 0.2 & 0.4 \\
\hline $\mathrm{SO}_{2}$ & 105 & 8.3 & 183 & 94 & $47^{*}$ & $125^{*}$ \\
\hline DMS & 6.6 & 1.8 & 4.7 & 3.6 & 1.2 & -0.70 \\
\hline $\mathrm{CS}_{2}$ & 3.1 & 0.68 & 2.5 & 2.1 & 2.2 & 1.6 \\
\hline OCS & 515 & 7.7 & 479 & 7.6 & $18^{*}$ & $-18^{*}$ \\
\hline $\mathrm{HCOOH}$ & 297 & 95 & 325 & 102 & $241^{*}$ & $269^{*}$ \\
\hline $\mathrm{CH}_{3} \mathrm{COOH}$ & 529 & 104 & 632 & 190 & 139 & 242 \\
\hline $\mathrm{H}_{2} \mathrm{O}_{2}$ & 886 & 171 & 663 & 207 & $524^{*}$ & $301^{*}$ \\
\hline $\mathrm{CH}_{3} \mathrm{OOH}$ & 390 & 70 & 305 & 109 & 9 & -76 \\
\hline Ethane & 943 & 42 & 714 & 48 & $483^{*}$ & $254^{*}$ \\
\hline Ethene & 28 & 3.0 & 23 & 6.6 & $16^{*}$ & $11^{*}$ \\
\hline Propane & 120 & 12 & 67 & 9.9 & $101^{*}$ & $48 *$ \\
\hline$i$-Butane & 16 & 3.1 & 9.8 & 3.6 & $\geq 16$ & $\geq 10$ \\
\hline$n$-Butane & 26 & 5.8 & 14 & 4.7 & $\geq 26$ & $\geq 14$ \\
\hline Ethyne & 223 & 27 & 162 & 24 & $260^{*}$ & $123 *$ \\
\hline 1-Butene & 6.5 & 1.4 & 6.6 & 3.3 & 1.8 & 2.0 \\
\hline$i$-Pentane & 9.7 & 1.7 & 8.6 & 4.2 & $\geq 10$ & $\geq 9$ \\
\hline$n$-Pentane & 7.9 & 1.8 & 5.7 & 2.1 & $\geq 8$ & $\geq 6$ \\
\hline$n$-Hexane & 4.3 & 1.4 & 5.1 & 8.6 & $\geq 4$ & $\geq 5$ \\
\hline Benzene & 48 & 7.3 & 30 & 5.5 & $40^{*}$ & $20 *$ \\
\hline "F & 266 & 0.85 & 264 & 1.2 & $4.0^{*}$ & $2.0^{*}$ \\
\hline${ }^{12} \mathrm{~F}$ & 502 & 0.92 & 501 & 1.7 & $6.0^{*}$ & $5.0^{*}$ \\
\hline${ }^{113} \mathrm{~F}$ & 77 & 0.69 & 77 & 0.63 & 1.0 & 1.0 \\
\hline $\mathrm{CH}_{3} \mathrm{CCl}_{3}$ & 122 & 2.1 & 125 & 3.6 & 3.0 & 4.0 \\
\hline $\mathrm{CCl}_{4}$ & 108 & 1.1 & 109 & 1.3 & -1.0 & 0 \\
\hline $\mathrm{C}_{2} \mathrm{Cl}_{4}$ & 3.9 & 0.56 & 3.1 & 0.29 & $1.7^{*}$ & $0.90^{*}$ \\
\hline $\mathrm{C}_{3} \mathrm{H}_{8} / \mathrm{C}_{2} \mathrm{H}_{6}$ & 0.12 & 0.008 & 0.14 & 0.07 & $\approx 0.08 *$ & $\approx 0.10^{*}$ \\
\hline $\mathrm{C}_{2} \mathrm{H}_{2} / \mathrm{CO}$ & 1.9 & 0.18 & 1.5 & 0.18 & $1.5^{*}$ & $1.1^{*}$ \\
\hline $\mathrm{NO}_{3}^{-}$ & 42 & 68 & 28 & 9.5 & $29^{*}$ & 15 \\
\hline nss-SO ${ }_{4}{ }^{2 \cdot}$ & 82 & 71 & 34 & 23 & $58^{*}$ & 10 \\
\hline $\mathrm{NH}_{4}^{+}$ & 121 & 83 & 43 & 9.0 & $\approx 300$ & $\approx 20$ \\
\hline${ }^{210} \mathrm{~Pb}$ & 8.2 & 4.5 & 6.1 & 2.4 & $7.7^{*}$ & $5.6^{*}$ \\
\hline${ }^{7} \mathrm{Be}$ & 304 & 154 & 243 & 207 & NA & NA \\
\hline
\end{tabular}

Significant enrichment or depletion of species in outflow relative to aged (south) marine air illustrates the asian emission signature. C.I., Confidence Interval.

*Indicates species significantly $(p=0.05)$ enriched or depleted in continental outflow comparied to aged (south) marine air.

activity are probably sources for many of these species [Kato and Akimoto, 1992].

Biogenic activities on the Asian continent may exert important influence on the atmospheric distribution of several trace gases over the western Pacific Ocean [Matsueda et al., 1993]. For example, the $\mathrm{CO}_{2}$ data indicate uptake of it over the continents, with the strongest sink over the heavily vegetated CS region. This also appears to be the case for OCS, where it appears to have a net atmospheric sink over the CS region but be released from the $\mathrm{CN}$ area. Asia is also implicated to be a net source of $\mathrm{CH}_{4}$, with the strongest sources over the Southeastern continent. At least part of the $\mathrm{CH}_{4}$ enhancement is undoubtedly due to its release from wetland ecosystems in southeast Asia [Bachelet and Neue, 1993; Khalil et al., 1990]. However, anthropogenic activities are also likely sources of $\mathrm{CH}_{4}$ in Asia [Khalil et al., 1990].

Recent estimates of Asian atmospheric emissions of $\mathrm{SO}_{2}$ and $\mathrm{NO}_{\mathrm{x}}$ reveal that Chinese sources are rich in sulfur $\left(10 \mathrm{Tg} \mathrm{S} \mathrm{yr} \mathrm{r}^{-1}\right)$ and lower in nitrogen $\left(2.24 \mathrm{Tg} \mathrm{N} \mathrm{yr}^{-1}\right)$ content $(\mathrm{H}$. Akimoto et al., Atmospheric chemistry of the East-Asian northwest Pacific region, submitted to Proceedings of the 37th Conference in the OHOLO 
Conference series, 1994]. The other Pacific rim countries, including Japan, together release annually $1.62 \mathrm{Tg} S$ and $1.02 \mathrm{Tg}$ $\mathrm{N}$ to the atmosphere. The resultant nss- $\mathrm{SO}_{4} / \mathrm{NO}_{3}$ emission ratio should range from 3.01 over China to 0.57 near Japan [Arimoto et al., this issue]. Values within this range were observed at the PEM-West A ground level sampling stations and in aerosol samples collected from the DC-8 at $\mathbf{0 . 3} \mathrm{km}$ altitude near Taiwan [Arimoto et al., this issue].

Examination of the $\mathrm{NO}_{\mathrm{y}}$ signals from air masses originating over the $\mathrm{CN}$ and $\mathrm{CS}$ source regions shows the potential for similar emission strengths from each. In fact, the PEM-West A aircraft data indicate a somewhat different picture than that observed at the ground level stations. The aircraft data set indicates a Pacific rim region that is regionally rich in atmospheric emissions of nitrogen relative to sulfur. Ground level studies, however, clearly show a strong influence of anthropogenic sulfur emissions relative to nitrogen in this area [Zhao and Xiong, 1988; Galloway, 1989; Arimoto et al., this issue]. Since we do not know the initial composition of the air masses feeding eastward into the $\mathrm{CN}$ and CS source regions, it is not possible to determine with our present data set how much of the $\mathrm{NO}_{\mathrm{y}}$ (or any other species) originated from Asia compared to what was already in the "background" air.

Particularly in the middle to upper tropospheric region, it is possible that other source regions contributed substantially to the chemistry. The wind speeds are very large in the upper troposphere $\left(60-70 \mathrm{~m} \mathrm{~s}^{-1}\right)$, and this could bring several-day-old emissions from Europe into our study region [Newell et al., this issue]. The so-called "Japan jet" is coupled to this rapid upper tropospheric transport and it is known to carry Asian continental emissions across the North Pacific to California on a timescale of 3 days or less [Kritz et al., 1990].

The PEM-West A upper tropospheric data are not inconsistent with a biomass-burning source signature. Species such as $\mathrm{CO}$, $\mathrm{C}_{2} \mathrm{H}_{6}$, and $\mathrm{NO}_{\mathrm{y}}$ should be enhanced in such emissions with little likelihood of inputs of industrial tracer compounds. Biomass burning in southeastern Asia and on the various islands chains to the south may have been active during our study period. We did, in fact, encounter over the Celebes Sea what appeared to be a biomass fire plume emerging from the Borneo region [Blake et $a l$, this issue]. In addition, there is extensive use of biomass materials for household cooking and space heating in Asia [Galloway, 1989]. Convective activity could transport these combustion emissions to high altitude where they would have a good opportunity to be rapidly swept into our study region [Newell et al., this issue].

European emissions could also contribute to the chemistry at high altitude, but they should contain significant amounts of industrial tracer compounds. The fact that the mixing ratios of industrial tracers (e.g., $\mathrm{C}_{2} \mathrm{Cl}_{4}$ and $\mathrm{CH}_{3} \mathrm{CCl}_{3}$ ) at high altitude were near those of aged marine air over the Pacific argues against a European influence.

The PEM-West A data indicate that Asian sources are significant contributors of chemical species to the atmosphere over the western Pacific. The direct outflow at low altitude was clearly of Asian origin. It is a complicated issue, however, to confidently identify a unique Asian signature from other potential long-range sources to the free troposphere over the western Pacific.

\section{Conclusions}

We have presented the chemical characteristics of Asian continental outflow over the western Pacific Ocean. Mixing ratios of most species and the ratios $\mathrm{C}_{2} \mathrm{H}_{2} / \mathrm{CO}$ and $\mathrm{C}_{3} \mathrm{H}_{8} / \mathrm{C}_{2} \mathrm{H}_{6}$ were very similar in air masses classified as $<2$ and 2 - 5 days of transport from over the Pacific rim landmasses. It appears that much of the outflowing air had already undergone significant photochemical processing before being advected over the western Pacific Ocean.

At low altitude the chemistry was clearly dominated by Asian source emissions under outflow conditions. In the free troposphere the situation was much more complex, with the possibility of a mixture of Asian and long-range transport influencing the distribution of trace gases and aerosol species. In addition, biogenic metabolism processes on the Asian continent appear to be important for influencing the distribution of $\mathrm{CO}_{2}, \mathrm{CH}_{4}$, and OCS over the western Pacific.

Acknowledgments. We appreciate the support provided by the DC-8 flight and ground crews at the NASA Ames Research Center. This research was supported by the NASA Global Tropospheric Chemistry program.

\section{References}

Atlas, E., and C. S. Giam, Global transport of organic pollutants: Ambient concentrations in the remote marine atmosphere, Science, 211, 163-165, 1981.

Arimoto, R., R. A. Duce, D. L. Savoie, J. M. Prospero, R. Talbot, J. D. Cullen, U. Tomza, N. F. Lewis, and B. J. Ray, Relationships among aerosol constituents from Asia and the North Pacific during PEM-West A, J. Geophys. Res., this issue.

Bachelet, D., and H. U. Neue, Methane emissions from wetland rice areas of Asia, Chemosphere, 26, 219-238, 1993.

Bachmeier, A. S., R. E. Newell, M. C. Shipham, Y. Zhu, D. R. Blake, and E. V. Browell, PEM-West A: Metoẹorological overview, J. Geophys. Res., this issue.

Balkanski, Y. J., D. J. Jacob, G. M. Gardner, W. C. Graustein, and K. K. Turekian, Transport and residence time of tropospheric aerosols inferred from a global three-dimensional simulation of ${ }^{210} \mathrm{~Pb}, J$. Geophys. Res., 98, 20,573-20,586, 1993.

Blake, D. R., T.-Y. Chen, T. W. Smith, Jr., C. J.-L. Wang, O. W. Wingenter, N. J. Blake, F. S. Rowland, and E. W. Mayer, Threedimensional distributions of nonmethane hydrocarbons (NMHCs) and halocarbons over the northwestern Pacific during the 1991 Pacific Exploratory Missions (PEM-West A), J. Geophys. Res., this issue.

Blank, M., M. Leinen, and J. M. Prospero, Major Asian aeolian inputs indicated by the mineralogy of aerosols and sediments in the western North Pacific, Nature, 314, 84-86, 1985.

Browell, E. V., et al., Large-scale air mass characteristics observed over the western Pacific during the summertime, J. Geophys. Res., this issue.

Buat-Menard, P., V. Ezat, and A. Gaudichet, Size distribution and mineralogy of aluminosilicate dust particles in tropical Pacific air and rain, in Precipitation Scavenging, Dry Deposition and Resuspension, vol. 2, edited by H. R. Prupracher, R. G. Semonin, and W. G. N. Slinn, pp. 1259-1269, Elseiver, New York, 1983.

Chin, M., and D. D. Davis, Global sources and sinks of OCS and $\mathrm{CS}_{2}$ and their distributions, Global Biogeochem. Cycles, 2, 321-338, 1993.

Dibb, J. E., R. W. Talbot, K. I. Klemm, G. L. Gregory, H. B. Singh, J. D. Bradshaw, and S. T. Sandholm, Asian influence over the western North Pacific during the fall season: Inferences from lead 210, soluble ionic species, and ozone, J. Geophys. Res., this issue.

Duce, R. A., C. K. Unni, B. J. Ray, J. M. Prospero, and J. T. Merrill, Long-range atmospheric transport of soil dust from Asia to the tropical North Pacific: Temporal variability, Science, 209, 1522-1524, 1980.

Duce, R. A., R. Arimoto, B. J. Ray, C. K. Unni, and P. J. Harder, Atmospheric trace elements at Enewetak Atoll: Concentrations, sources, and temporal variability, J. Geophys. Res., 88, 5321-5342, 1983.

Gagosian, R. B., E. T. Peltzer, and O. C. Zafiriou, Atmospheric transport of continentally derived lipids to the tropical North Pacific, Nature, 291, 312-314, 1981.

Gagosian, R. B., O. C. Zafiriou, E. T. Peltzer, and J. B. Alford, Lipids in aerosols from the tropical North Pacific: Temporal variability, $J$. Geophys. Res., 87, 11,133-11,144, 1982. 
Galloway, J. N., Atmospheric acidification: Projections for the future, Ambio, 18, 161-166, 1989.

Gregory, G. L., A. S. Bachmeier, D. R. Blake, B. G. Heikes, D. C. Thomton, A. R. Bandy, J. D. Bradshaw, and Y. Kondo, Chemical signatures of aged Pacific marine air: Mixed layer and free troposphere as measured during PEM-West A, $J$. Geophys. Res., this issue.

Harriss, R. C., G. W. Sachse, J. E. Collins Jr., L. Wade, K. B. Bartlett, R. W. Talbot, E. V. Browell, L. A. Barrie, G. F. Hill, and L. G. Burney, Carbon monoxide and methane over Canada: July - August 1990, $J$. Geophys. Res., 99, 1659-1669, 1994.

Hoell, J. M., Jr., D. D. Davis, S. C. Liu, R. Newell, M. Shipham, K. Akimoto, R. J. McNeal, R. J. Bendura, and J. W. Drewry, The Pacific Exploratory Mission-West A: September-October 1991, J. Geophys. Res., this issue.

Hubler, G., et al., Total reactive oxidized nitrogen $\left(\mathrm{NO}_{y}\right)$ in the remote Pacific troposphere and its correlation with $\mathrm{O}_{3}$ and $\mathrm{CO}$ : Mauna Loa Observatory, J. Geophys. Res., 97, 10,427-10,447, 1992.

Kato, $\mathrm{N}$., and $\mathrm{H}$. Akimoto, Anthropogenic emissions of $\mathrm{SO}_{2}$ and $\mathrm{NO}_{\mathrm{x}}$ in Asia: Emission inventories, Atmos. Environ., 26(A), 2997-3017, 1992.

Khalil, M. A. K., R. A. Rasmussen, M. -X. Wang, and L. Ren, Emissions of trace gases from Chinese rice fields and biogas generators: $\mathrm{CH}_{4}$ $\mathrm{N}_{2} \mathrm{O}, \mathrm{CO}, \mathrm{CO}_{2}$, chlorocarbons, and hydrocarbons, Chemosphere, 20 , 207-226, 1990 .

Kleinman, L. I., and P. H. Daum, Vetical distribution of aerosol particles, water vapor, and insoluble trace gases in convectively mixed air, $J$. Geophys. Res., 96, 991-1005, 1991.

Kondo, Y., H. Ziereis, M. Koike, S. Kawakami, G. L. Gregory, G. W. Sachse, H. B. Singh, D. D. Davis, and J. T. Merrill, Reactive nitrogen over the Pacific Ocean during PEM-West A, J. Geophys. Res., this issue.

Kritz, M. A., J.-C. Le Roulley, and E. F, Danielsen, The China Clipper-Fast advective transport of radon-rich air from the Asian boundary layer to the upper troposphere near California, Tellus, 42(B), 46-61, 1990.

Liu, S. C., et al., A model study of tropospheric trace species distributions during PEM-West A, J. Geophys. Res., this issue.

Matsueda, H., H. Inoue, and M. Ishii, Latitudinal distributions of methane in the upper troposphere and marine boundary layer air over the Pacific in 1990, Geophys. Res. Lett., 20, 695-698, 1993.

Merrill, J. T., Trajectory results and interpretation for PEM-West A, J. Geophys. Res., this issue.

Merrill, J. T., R. Bleck, and L. Avila, Modelling atmospheric transport to the Marshall Islands, J. Geophys. Res., 90, 12,927-12,936, 1985

Murphy, D. M., D. W. Fahey, M. H. Proffitt, S. C. Liu, K. R. Chan, C. S. Eubank, S. R. Kawa, and K. K. Kelly, Reactive nitrogen and its correlation with ozone in the lower stratosphere and upper troposphere, J. Geophys. Res., 98, 8751-8773, 1993.

Newell, R. E., S. T. Shipley, V. S. Connors, and H. G. Reichle Jr., Regional studies of potential carbon monoxide sources based on space shuttle and aircraft measurements, J. Atmos. Chem., 6, 61-81, 1988.

Newell, R. E., et al., Atmospheric sampling of supertyphoon Mireille with the NASA DC-8 aircraft on September 27, 1991, during PEM-West A, $J$. Geophys. Res, this issue.

Prospero, J. M., D. L. Savoie, Effect of continental sources on nitrate concentrations over the Pacific Ocean, Nature, 339, 687-689, 1989.

Prospero, J. M., D. L. Savoie, R. T. Nees, R. A. Duce, and J. Merrill, Particulate sulfate and nitrate in the boundary layer over the North Pacific Ocean, J. Geophys. Res., 90, 10,586-10,596, 1985.
Sandholm, S. T., et al., Summertime tropospheric observations related to $\mathrm{N}_{x} \mathrm{O}_{y}$ distributions and partitioning over Alaska: Arctic Boundary Layer Expedition 3A, J. Geophys. Res., 97, 16,481-16,509, 1992.

Sandholm, S. T., et al., Summertime partitioning and budget of $\mathrm{NO}_{y}$ compounds in the troposphere over Alaska and Canada, J. Geophys. Res., 99, 1837-1861, 1994.

Savoie, D. L., and J. M. Prospero, Comparison of oceanic and continental sources of non-sea-salt sulphate over the Pacific Ocean, Nature, 339, 685-687, 1989.

Savoie, D. L., J. M. Prospero, J. T. Merrill, and M. Uematsu, Nitrate in the atmospheric boundary layer of the tropical South Pacific: Implications regarding sources and transport, J. Atmos. Chem., 391$415,1989$.

Settle, D. M., and C. C. Patterson, Magnitudes and sources of precipitation and dry deposition fluxes of industrial and natural leads to the North Pacific at Enewetak, J. Geophys. Res., 87, 8857-8869, 1982.

Singh, H. B., and P. B Zimmerman, Atmospheric distribution and sources of nonmethane hydrocarbons, in Gaseous Pollutants: Characterization and Cycling, John Wiley, New York, 1992.

Smyth, S., et al., Comparison of free tropospheric western Pacific air mass classification schemes for the PEM-West A experiment, $J$. Geophys. Res., this issue.

Talbot, R. W., K. M. Beecher, R. C. Harriss, and W. R. Cofer III, Atmospheric geochemistry of formic and acetic acids at a midlatitude temperate site, J. Geophys. Res., 93, 1689-1698, 1988.

Turekian, K. K., and J. K. Cochran, ${ }^{210} \mathrm{~Pb}$ in surface air at Enewetak and the Asian dust flux to the Pacific, Nature, 292, 522-524, 1981.

Uematsu, M., R. A. Duce, J. M. Prospero, L. Chen, J. T. Merrill, and R. L. McDonald, Transport of mineral aerosol from Asia over the North Pacific Ocean, J. Geophys. Res., 88, 5343-5352, 1983.

Zhao, D., and J. Xiong, Acidification in southwestern China, in Acidification in tropical countries, edited by $\mathrm{H}$. Rodhe and R. Herrera, John Wiley, New York, 1988.

B. E. Anderson, J. Collins, G. L. Gregory, and G. W. Sachse, NASA Langley Research Center, Hampton, VA 23665.

D. R. Blake, Department of Chemistry, Univeristy of California-Irvine, Irvine, CA 92715

J. D. Bradshaw and S. T. Sandholm, School of Earth and Atmospheric Sciences, Georgia Institute of Technology, Atlanta, GA 30332.

J. E. Dibb, Institute for the Study of Earth, Oceans, and Space, Morse Hall, University of New Hampshire, Durham, NH 03824-3525.

B. G. Heikes and J. T. Merrill, Center for Atmospheric Chemistry, University of Rhode Island, Narragansett, RI 02882.

K. I. Klemm, Fraunhofer Institute für Atmosphărische Umweltforschung, Garmisch-Partenkirchen, Germany.

H. B. Singh, NASA Ames Research Center, Moffett Field, CA 94035.

R. W. Talbot (corresponding author), Complex Systems Research Center, University of New Hampshire, Morse Hall, Durham, NH 038243525. (e-mail: rwt@christa.unh.edu)

D. C. Thornton, Department of Chemistry, Drexel University, Philadelphia, PA 19104.

Paper number 95JD02363

0148-0227/96/95JD-02363\$05.00 